This PDF is a selection from a published volume from the National Bureau of Economic Research

Volume Title: Measuring Economic Sustainability and Progress

Volume Author/Editor: Dale W. Jorgenson, J. Steven Landefeld, and Paul Schreyer, editors

Volume Publisher: University of Chicago Press

Volume ISBN: 0-226-12133-X (cloth); 978-0-226-12133-8

(cloth); 978-0-226-12147-5 (eISBN)

Volume URL: http://www.nber.org/books/jorg12-1

Conference Date: August 6-8, 2012

Publication Date: September 2014

Chapter Title: Toward the Development of Sectoral Financial Positions and Flows in a From-Whom-to-Whom Framework

Chapter Author(s): Manik Shrestha

Chapter URL: http://www.nber.org/chapters/c12835

Chapter pages in book: (p. $373-425)$ 


\title{
Toward the Development of Sectoral Financial Positions and Flows in a From-Whom-to-Whom Framework
}

\author{
Manik Shrestha
}

\subsection{Introduction}

In the wake of the 2008 financial and economic crisis, the G-20 economies asked the Financial Stability Board (FSB) and the International Monetary Fund (IMF) to identify data gaps shedding light on economic and financial vulnerabilities, and make recommendations whose implementation by countries would close those gaps. The FSB and IMF came up with twenty recommendations covering a wide range of economic and financial statistics. The IMF and the FSB undertook extensive consultations with users and compilers of economic and financial statistics ${ }^{1}$ and produced a set of recommendations structured around four themes: buildup of risks in the financial sector, cross-border financial linkages, vulnerability of domestic economies to shocks, and improving communication of official statistics. ${ }^{2}$ These data initiatives are known as the G-20 Data Gaps Initiative ${ }^{3}$ (DGI) that has been

Manik Shrestha is lead statistical methodologist in the Statistics Department of the International Monetary Fund.

I would like to thank Segismundo Fassler and Reimund Mink for their collaboration with me to prepare an IMF working paper (WP/12/57) titled "An Integrated Framework for Financial Positions and Flows on a From-Whom-to-Whom Basis: Concepts, Current Status, and Prospects" (see Shrestha, Mink, and Fassler 2012). This chapter is a sequel to this IMF working paper. The views expressed here are those of the author and should not be attributed to the IMF, its executive board, or its management. For acknowledgments, sources of research support, and disclosure of the author's material financial relationships, if any, please see http:// www.nber.org/chapters/c12835.ack.

1. For instance, the senior officials conference of July 2009, the papers for which are available at http://www.imf.org/external/np/seminars/eng/2009/usersconf/index.htm. Information on subsequent global conferences is available at http://www.imf.org/external/data.htm.

2. For a brief description of current status and policy relevance of these data initiatives, see Heath (2013).

3. See http://www.imf.org/external/np/g20/pdf/102909.pdf and www.imf.org/external/data .htm\#add. 
endorsed by the G-20 finance ministers and central bank governors ${ }^{4}$ and the IMF's International Monetary and Financial Committee. To coordinate the work among the international agencies, the IMF set up the Inter-Agency Group on Economic and Financial Statistics (IAG). ${ }^{5}$

Recommendation 15 of the DGI calls for developing "a strategy to promote the compilation and dissemination of the balance sheet approach, flow of funds, and sectoral data more generally, starting with the G-20 economies." The objective of Recommendation 15 is to expand the dissemination and reporting of internationally comparable and detailed full sequence of national accounts by institutional sectors on an annual and quarterly basis by both G-20 economies as well as non-G-20 advanced and emerging market economies. This expansion would involve improving the compilation of sectoral national accounts in terms of details (subsectors and asset details), closing data gaps, and developing financial positions and flows on a from-whom-to-whom basis. This chapter emphasizes the development of integrated macroeconomic accounts that relate income, current expenditures, disposable income, saving, investment in nonfinancial assets and financial assets, revaluation and other changes in assets and liabilities, changes in net worth, and balance sheets. The chapter, however, focuses on the implementation of sectoral financial positions and flows on a fromwhom-to-whom basis.

The functioning of economic and financial systems involves interactions/ exchanges and debtor/creditor relationships among all economic entities that may have different motivations and functions, engage in different activities, and have different behaviors. With the increasing role of domestic and international markets, which are becoming more complex, sophisticated, and integrated as well as innovating new products and services, the nature and intensity of interrelationships and linkages among and within groups of entities (subsectors) and among and within the various functions (for example, production, consumption, capital accumulation, and financial investment) are also going through drastic transformations. It is, therefore, imperative to understand not only the characteristics of a subsector or a function, but also the interlinkages among the subsectors and functions. The analytic and policy responses related to a subsector or a function should take into account the intended and unintended implications on other subsectors and functions. Only an integrated statistical framework that presents

4. The Communiqué of Finance Ministers and Central Bank Governors of the G-20, Mexico City, Mexico, November 4-5, 2012, states that "Recognizing the need for adequate statistical resources, we endorse the progress report of the FSB and the IMF on closing information gaps, and in particular look forward to the implementation of the data reporting templates for global systemically important financial institutions." http://www.g20mexico.org.

5. The members of the IAG are the Bank for International Settlements (BIS), the European Central Bank (ECB), Eurostat, the IMF (Chair), the Organisation for Economic Co-operation and Development (OECD), the United Nations Statistics Division (UNSD), and the World Bank. This work is undertaken in consultation with the FSB. 
macroeconomic statistics for all sectors and subsectors in a consistent way can meet the analytic and policy needs for information arising from highly interconnected economic and financial systems.

Academics, analysts, and policymakers have given increasing attention to the balance sheets and wealth of the economic sectors because financial and economic crises are characterized by abrupt revaluations or other changes in the capital positions of key sectors of the economy. The data of interest thus comprise not only the balance sheets but also the accumulation accounts for each economic sector within an economy, showing the level as well as the change in sectoral balance sheet positions broken down into three of the principal types of flows in the System of National Accounts (SNA): changes in position arising from transactions, revaluations, and other changes in the volume of assets. Although sectoral balance sheets and accumulation accounts, integrated with sectoral current accounts showing production, income and current expenditure flows, are envisaged in the present and two previous national accounting standards, their implementation has been uneven even among the advanced economies.

The global crisis of 2008 highlighted particularly the need to understand financial interconnectedness among the various sectors of an economy and between them and their counterparties in the rest of the world. This kind of analysis has been most seriously hampered by the lack of adequate data among the G-20 economies. Although some recent improvements in the development of statistical methodologies and data availability have supported the compilation of partial financial balance sheet and accumulation account data on a from-whom-to-whom basis, a fully integrated approach for sectoral financial positions and flows within the macroeconomic statistics framework is yet to be achieved. Thus, Recommendation 15 also implies, through its reference to compiling "flow of funds" statistics, compilation of breakdowns of the financial positions and flows of each economic sector by its counterparty sectors. Data sets providing this kind of information are said to provide "from-whom-to-whom" financial statistics, also known as "three-dimensional approach for presenting financial statistics that provide both debtor and creditor information for each financial instrument."

The SNA provides an integrated framework for developing sectoral financial positions and flows on a from-whom-to-whom basis because its underlying principles ensure that the linkages of the economic and financial actions of an economy are captured. ${ }^{6}$ However, the SNA's standard presentation is not explicitly designed to show the intersectoral linkages, as traditionally it has focused primarily on answering "who does what," but not "who does what with whom." As the SNA is the internationally

6. In 2008 the United Nations Statistical Commission approved the System of National Accounts 2008 (2008 SNA). The final version of the 2008 SNA was released by the UN in September 2009 on its external website at http://unstats.un.org/unsd/nationalaccount/sna2008.asp. 
accepted methodology for the compilation of the national accounts, the lack of prominence it gives to the from-whom-to-whom principle for data compilation and presentation may be one of the reasons why these statistics are not more widely available.

Promoting the implementation of the SNA sectoral accounts with fromwhom-to-whom intersectoral relationships for financial positions and flows is thus an important step in filling one of the most significant data gaps identified during the 2008 global crisis. The integrated framework on a fromwhom-to-whom basis allows answering questions like "Who is financing whom, in what amount, and with which type of financial instrument?" A key lesson from the 2008 global crisis is that understanding the balance sheet strength of an entity or a subsector alone is not sufficient. It is also important to understand risks, vulnerabilities, and spillover effects arising from the financial interconnection. Regarding the allocation of income, it also permits tracing who is paying/receiving income (e.g., interest) to/from whom. The from-whom-to-whom compilation approach also enhances the quality and consistency of data by providing a systematic tool for cross-checking, data validation, and balancing opportunities as well as filling data gaps.

Countries are at different stages of implementation of the sectoral accounts and balance sheets. Designing and implementing changes to or initiating new data collection systems are costly and priorities must therefore be established among the various potential improvements. Implementation of sectoral financial positions and flows on a from-whom-to-whom basis is considered to be the most challenging in terms of resource requirements and data collection. Further, more detailed data on a counterparty basis implies a need to address the issue of confidentiality, especially for small economies or highly specialized economies.

The flexibility provided by the SNA in terms of the level of detail of data compilation and presentation should also allow the use of this framework to comply with the requirements of other analytical tools for the assessment of financial vulnerabilities and risks. One such tool is the IMF's balance sheet approach (BSA) that provides a breakdown of counterparty positions in financial assets and liabilities by maturity and currency (domestic and foreign).

Following this introduction, section 12.2 of this chapter elaborates how the SNA can provide an integrated framework for compiling sectoral financial positions and flows on a from-whom-to-whom basis and ensure consistency among the different domains of the macroeconomic accounts. Section 12.3 describes developments in accounting on a from-whom-to-whom basis. Section 12.4 discusses the initiatives at the international and country levels for the implementation of the integrated sectoral national accounts and balance sheets. Section 12.5 contains some preliminary thoughts on implementing the three-dimensional approach for compiling data on sectoral financial positions and flows, and section 12.6 provides some concluding remarks. 


\subsection{The SNA Integrated Accounts}

12.2.1 Depicting the Economy: Relationships between Economic Agents through Economic and Financial Flows and Financial Positions

Understanding the functioning of an economy requires a comprehensive picture of the economic actions covering all aspects of the economic and financial activities. The main economic activities take place in the spheres of production, income distribution and use, and accumulation. On a schematic form the economic cycle can be described as follows: the economic agents interact in the production of goods and services, the income generated in production is distributed among the participants in this process between capital and labor contributions, a redistribution of income among the economic agents is made through current transfers, income is used for consumption or saving, and savings plus net capital transfers received provide own sources for financing investment ("real" and financial). If own financing resources are lower than the funds needed for real investment, the deficit of funds is filled by incurring financial liabilities and/or disposing of financial assets (net borrowing). Correspondingly, if own financing resources exceed the funds needed for real investment, the surplus is reflected in acquisitions of additional financial assets and/or the extinguishing of liabilities (net lending).

Economic entities with a surplus of funds will acquire financial assets or extinguish their liabilities or both. Entities with a deficit of financing will incur liabilities or be obliged to dispose financial assets to fill the financing gap. In other words, economic actions taken place in the "real" sphere of the economy have consequences in the "financial" sphere. A debtor/creditor relationship is established between entities with a financing gap (borrowers) and those with excess funds (the creditors). In the recent periods, the debtor/ creditor relationships created within the financial markets for speculative purposes have grown substantially and become more complex.

The SNA provides an integrated statistical framework for presenting relationships between economic flows in the real and the financial spheres of the economy as well as the debtor/creditor relationships. The quadruple-entry consistency imposed on the data, while ensuring conceptual consistency, creates practical challenges for compilers due to inevitable data gaps and differences (both conceptual and other; for example, coverage, details, frequency, and timeliness) among data sources and between micro- and macroaccounting. Particularly with respect to the data consistency between real and financial transactions (net lending/borrowing derived from nonfinancial transactions with that derived from financial transactions), country practices show the strength of the statistical framework for developing vertical (for example, the relationship between real and financial transactions for a subsector) and horizontal (for example, claims of all holders of a debt secu- 
rity on its issuers) consistency methods to enhance data quality. Achievements in the adoption of uniform business accounting standards and public sector accounting standards as well as the consistency between these two will contribute to the consistency of the macroaccounts. Still, it should be kept in mind that accounting standards are geared toward individual units and therefore not necessarily assure interunit consistency. Close collaboration among the various data collection systems is being emphasized more to ensure data consistency. Data consistency should, therefore, be addressed at all stages of data collection and compilation. It should be recognized that it may not be possible to resolve some discrepancies within a given statistical infrastructure. In such a case, the discrepancies should be shown explicitly, causes for them should be explained, their development should be closely monitored, and plans for possible resolution should be adopted.

The SNA follows the residence approach to record flows and positions of institutional units, grouped into sectors and subsectors, resident in an economy between them and with nonresidents. It may not be able to provide for full risk-based measures for macroprudential analysis and for financial stability purposes particularly when cross-border operations (through branches and subsidiaries) controlled by home country entities grow in significance.

In the wake of the 2008 global crisis a need has been identified for the development of statistics on a worldwide-group-consolidated basis - showing also the cross-border financial activities of corporate groups including potentially intragroup flows and positions as formulated in Recommendation 13 of the G-20 report mentioned earlier. ${ }^{7}$ Large groups of financial or nonfinancial corporations or conglomerates exist whereby a parent corporation controls several subsidiaries, some of which may control subsidiaries of their own, and so on. Therefore, the concept of a corporate group deviates from the grouping or aggregating of institutional units to an institutional sector as the corporate group concept puts together institutional units based on the concept of control. Such an approach complements the macroeconomic analysis based on the SNA approach.

\subsubsection{What the SNA Offers to Ensure the Integrated Framework}

The SNA offers the following attributes to ensure that it provides an integrated framework for capturing and presenting macroeconomic statistics on a residency basis:

1. The SNA includes all resident institutional units grouped into subsectors and sectors and nonresident institutional units grouped into the rest of the world.

7. See the FSB/IMF reports on the G-20 Data Gaps Initiative mentioned in footnote 3. 
2. The SNA includes all economic flows and stocks of resident institutional (sub)sectors and between residents and nonresidents.

3. The SNA applies a consistent set of accounting principles, concepts, and classifications.

4. The SNA uses uniform accounting structures for all resident institutional units grouped into subsectors and sectors and for the rest of the world.

A brief description of each of these attributes is given below.

\section{Institutional Units and Sectors and Subsectors}

Institutional units, according to the SNA, are the economic units that can engage in transactions and can own assets and incur liabilities on their own behalf. Institutional units are grouped together into institutional sectors, based on their functions, behavior, and objectives. The SNA distinguishes five main institutional sectors (nonfinancial corporations, financial corporations, general government, households, and nonprofit institutions serving households). It also provides for a hierarchical classification for further dividing the sectors into subsectors.

However, it should be kept in mind that if data on detailed institutional sectors are to be compiled for financial positions and flows on a from-whomto-whom basis, the breakdown of the data by sector and subsector is an important feature for analyzing creditor/debtor relationships. A further breakdown of the main SNA institutional sectors may therefore be necessary. The further subsectoral breakdowns of the financial corporations may be of importance given that they are at the center of the analysis of financial risks, vulnerabilities, and spillovers arising from their role in financial intermediation, the size of their assets holdings and liabilities, and the variety of financial instruments in their portfolios. For the financial corporations sector, the 2008 SNA recommends nine subsectors (central bank, deposittaking corporations other than central bank, money market funds [MMF], non-MMF investment funds, other financial corporations except insurance and pension funds, financial auxiliaries, captive financial institutions and money lenders, insurance corporations, and pension funds). Any corporate sector or subsector can be further classified into public, foreign controlled, and national private enterprises. The general government may be further divided into central, state, and local governments and social security can be identified separately for the general government as a whole or at each level of government. The implementation of the DGI for sectoral national accounts emphasizes more detailed sectoral breakdowns, particularly for subsectors of financial corporations (given the increased role of nonbank financial institutions) and separate reporting of public sector nonfinancial and financial sectors. 


\section{Economic Flows and Stocks}

The SNA uses a set of economic flows and stocks for describing the economic and financial activities of resident economic entities and of the rest of the world.

Economic flows are classified into transactions and other economic flows. Transactions cover economic actions between two economic entities by mutual agreement. The SNA also considers some economic actions undertaken within an economic unit as a transaction (e.g., an increase in inventories of own-produced output by a producer unit).

Economic flows that are not a result of transactions are called "other economic flows" in the SNA terminology. These flows are of two types: other changes in the volume of assets and liabilities, and revaluations. Other changes in the volume of assets and liabilities reflect changes affecting the wealth of an economic entity as a result of the appearance or disappearance of assets/liabilities (for example, losses from natural disasters or write off of a debt by the creditor). Revaluations (also known as holding gains and losses) reflect changes in the value of assets and liabilities due to changes in their prices, including exchange rates.

The balance sheet records stocks of nonfinancial assets and financial assets and liability positions. The stocks/positions are changed through transactions and other economic flows. Although the SNA recommends a standard classification of financial assets and liabilities for flows and positions that provides the basis for the comparison of data across countries, it also recognizes that further breakdowns of assets and liabilities may be required to meet specific analytical needs and country-specific circumstances. In particular, remaining maturity and currency breakdowns have become more important for analyzing maturity and currency mismatches.

\section{Accounting Principles}

Accounting principles determine the bookkeeping conventions and entries, time of recording, and valuation.

Double and Quadruple Entry Accounting. As in business accounting, entries for an entity follow the double entry principle to register a transaction. Thus, for the entity undertaking the action there should be one entry as a debit and one as a credit for exactly the same value, ensuring vertical consistency of all transactions for this entity. It follows that when there is a transaction between two institutional units the double entry accounting principle implies that four entries are required in the accounts (two for each institutional unit carrying out the transaction) leading to a quadruple entry system. The quadruple entry accounting ensures vertical consistency (debits and credits for all transactions for an institutional unit are equal), horizontal consistency (debit entries of a transaction type for all entities are equal to 
the credit entries of that transaction type for all counterpart entities), and consistency in the counterparty relationship.

The quadruple entry accounting provides the underlying basis for developing data on a from-whom-to-whom basis. ${ }^{8}$ However, the SNA accounting structure (as described below) is not built to make explicit the relationship between two parties in a transaction as it aggregates (for each sector or the economy as a whole) all transactions of the same kind without distinguishing with whom these transactions take place. ${ }^{9}$

Time of Recording. One implication of the quadruple entry accounting principle is that entries related to a transaction and other economic flow should be recorded at the same time in the various accounts of the system for all counterparties involved. The SNA uses the accrual principle of accounting; that is, transactions between institutional units are to be recorded when claims and obligations arise, are transferred, transformed, or extinguished.

Valuation. The quadruple entry principle also implies that entries for a transaction as well as financial positions should be recorded at the same value for the counterparties involved. Thus, a financial asset and its counterpart liability are recorded for the same amount in the debtor and the creditor accounts. Transactions are recorded at the current market prices at the time the transaction takes place and positions are recorded at the point of time the balance sheet refers to.

\section{Concepts and Classifications}

The SNA concepts and definitions are drawn from economic theories and are applied consistently throughout the system. The SNA integrated accounts (transactions, other economic flows, and balance sheets) are built on the systematic classification of the following three pillars: (a) institutional units and (sub)sectors, (b) transactions and other flows, and (c) assets and liabilities. The SNA uses concepts of economic territory, production boundary, and asset boundary to define the scope of resident entities, transactions, other economic flows, nonfinancial assets, and financial assets and liabilities.

8. The principle of quadruple entry also allows the recording of transactions involving more than two parties. Cases in example are the trade of securities or other negotiable financial instruments on secondary markets and the assumption of guaranteed debt by the guarantor. In both cases three parties are involved - the two transactors as creditors and the debtor in the first case, and the guarantor, the original debtor, and the creditor in the second case.

9. Financial transactions between resident units are balanced by definition; that is, total (net) acquisition of assets is equal to total (net) incurrence of liabilities, therefore for the economy net acquisition of financial assets minus net incurrence of liabilities represent the net lending to (borrowing from) the rest of the world. Transactions between residents and nonresidents are shown in the accounts of the rest of the world, which records the financial transactions at a consolidated level of financial assets and liabilities without a breakdown by creditor sector or debtor sector. 


\section{Accounting Structure}

The accounting structure of the SNA is used to organize and present data on transactions, other economic flows, and stocks of assets and liabilities for the sectors and subsectors of an economy and the rest of the world.

The sequence of accounts on current transactions records consistently the production and generation, distribution and use of income, with savings as a balancing item. The sequence of current accounts is followed by the accumulation accounts. While all changes in assets, liabilities, and net worth are included in the accumulation accounts, the corresponding positions are shown in the balance sheet. The balance sheet comprises three elements: (a) nonfinancial assets (b) financial asset and liability positions, and (c) net worth as the balancing item between assets and liabilities. Drawing up a balance sheet makes it possible to focus on the net worth of a sector or subsector of an economy and how it changes over time. Accordingly, the change in net worth is composed of saving, net capital transfers receivable, holding gains less holding losses, and other (net) changes in the volume of assets or liabilities. Table 12.1 shows how transactions, other flows, and positions are presented in the SNA.

Flows and positions as presented in the SNA are somewhat incomplete as they cover only the flow accounts and balance sheets by (sub)sector without

Table 12.1

Flows and stocks/positions as presented in the SNA

\begin{tabular}{|c|c|c|c|c|}
\hline & Transactions & Other flows & Stocks/positions \\
\hline \multicolumn{2}{|c|}{ Current account } & $\begin{array}{l}\text { Production of goods and } \\
\text { services, generation, } \\
\text { distribution, redistribution, } \\
\text { and use of income }\end{array}$ & & \\
\hline \multirow{4}{*}{ 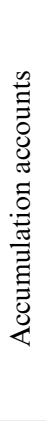 } & Capital account & $\begin{array}{l}\text { Net acquisition of } \\
\text { nonfinancial assets, saving } \\
\text { and capital transfers }\end{array}$ & & \\
\hline & $\begin{array}{l}\text { Financial } \\
\text { account }\end{array}$ & $\begin{array}{l}\text { Net acquisition of } \\
\text { financial assets and net } \\
\text { incurrence of liabilities }\end{array}$ & & \\
\hline & $\begin{array}{l}\text { Revaluation } \\
\text { account }\end{array}$ & & $\begin{array}{l}\text { Revaluation of } \\
\text { assets and liabilities }\end{array}$ & \\
\hline & $\begin{array}{l}\text { Other changes } \\
\text { in the volume of } \\
\text { assets account }\end{array}$ & & $\begin{array}{l}\text { Other changes in } \\
\text { volume of assets } \\
\text { and liabilities }\end{array}$ & \\
\hline \multicolumn{2}{|c|}{ Balance sheet } & & & $\begin{array}{l}\text { Nonfinancial assets. } \\
\text { financial assets and } \\
\text { liabilities, and net } \\
\text { worth as a balancing } \\
\text { item }\end{array}$ \\
\hline
\end{tabular}


detailed data by counterparty (sub)sector. That is, although they show which institutional sectors are acquiring assets, and what financial assets they are transacting in, they do not identify the sectors that incur the corresponding liabilities. Similarly, while they enable net borrowing sectors to be identified, and show how they borrow, the accounts do not show which sectors took up and hold the financial instruments. For a full understanding of financial positions and flows, it is important to know not just what types of liabilities a sector uses to finance its economic and financial activities, but also which sectors are providing the financing. In addition, it is often necessary to analyze financial transactions between subsectors of a sector, particularly for financial corporations and general government.

Chapter 27 of the 2008 SNA provides some inputs to an integrated framework of financial positions and flows on a from-whom-to-whom basis. It describes that detailed flow of funds accounts are based on three-dimensional tables. Such a table records transactions or financial asset and liability positions cross classified by type of asset, creditor sector, and debtor sector.

\subsubsection{The SNA and the From-Whom-to-Whom Approach for Financial Positions and Flows}

While the SNA's main accounting structure shows the accounts for each institutional (sub)sector without counterparty details, it provides the conceptual framework to present financial positions and flows in a fromwhom-to-whom framework. ${ }^{10}$ The main reason why the SNA is not overly explicit on a from-whom-to-whom presentation of financial statistics is the reporting burden it poses on compilers, in particular for securities and other negotiable financial instruments. However, the 2008 global crisis revealed the importance of understanding spillover effects on balance sheet vulnerabilities arising from financial linkages between sectors and with the rest of the world.

The Handbook on Securities Statistics (prepared by the Bank for International Settlements [BIS], European Central Bank [ECB], and IMF), in particular its part 2 on debt securities holdings, covers the conceptual framework for positions and flows as outlined in the SNA but also extends this approach by reflecting the from-whom-to-whom relationships. ${ }^{11}$ It presents the relationships between the resident sectors as creditors and residents and nonresidents as debtors, and between nonresidents as creditors and residents as debtors of financial instruments.

From a statistical point of view, the construction of the accounts on a from-whom-to-whom basis is an important compilation tool for enhancing

10. See chapter 27 of the 2008 SNA on the Links to Monetary Statistics and the Flow of Funds.

11. See Bank for International Settlements, European Central Bank and International Monetary Fund Handbook on Securities Statistics, part 1 (debt securities issues), part 2 (debt securities holdings), and part 3 (equity securities). http://www.imf.org/external/np/sta/wgsd /hbook.htm. 
the quality and consistency of the data. The fully integrated sectoral national accounts, balance sheets, and flow of funds would improve the integration of scattered information and highlight the inconsistencies between the data sets of the various macroeconomic domains as it ensures a holistic approach to all the sectors of an economy and rest of the world. The sectoral national accounts will provide an integration framework for macroeconomic data on external, fiscal, and financial sectors with those of the rest of the economy. At the country level, this will facilitate the coordination of work on different macroeconomic statistics domains and promote their consistency at the data collection and compilation stages, thus eliminating or significantly reducing inconsistency of disseminated data.

\subsubsection{Application of the SNA Framework for Presenting Intersectoral Linkages}

The SNA has not given a primary emphasis to the compilation of the accounts on a from-whom-to-whom basis. However, its underlying principles and framework allow for compiling such accounts. Moreover, the SNA itself provides, albeit on a secondary plan, some references to the compilation of the accounts on a three dimensional basis; that is, including the from-whom-to-whom information. In the case of the financial positions and flows it calls this presentation "detailed flows of funds." From-whomto-whom accounts permit tracing the debtor/creditor relationships between institutional sectors; that is, they can be used to show transactions, revaluations, other changes in financial assets and liabilities, and balance sheet positions cross classified by debtor sector and creditor sector.

Table 12.2 shows the integrated framework of accounts on a from-whomto-whom basis by institutional sector and the rest of the world in a matrix format. For an economy, it shows transactions for a financial instrument acquired by residents (grouped into sectors) and nonresidents vis-à-vis institutional units as debtors, broken down by residents (again grouped into sectors) and nonresidents. Similar accounts for each financial instrument can be prepared for financial positions, revaluation, and other volume changes.

For residents, the presentation of nonconsolidated data is recommended. This means that intrasectoral positions, transactions, revaluations, and other changes in the volume of assets and liabilities are not eliminated (cells shaded medium gray). The financial assets of nonresidents issued by nonresidents are not covered (black cell). These are not relevant from a national economy's perspective. For economies that are open to capital flows, information on counterparty economies and nonresident sectors becomes highly desirable.

The from-whom-to-whom financial account of an institutional sector or of the rest of the world is an extension of the nonconsolidated financial account (matching debtor and creditor sectors). Similarly, the from-whomto-whom financial balance sheet of a sector or of the rest of the world is an 


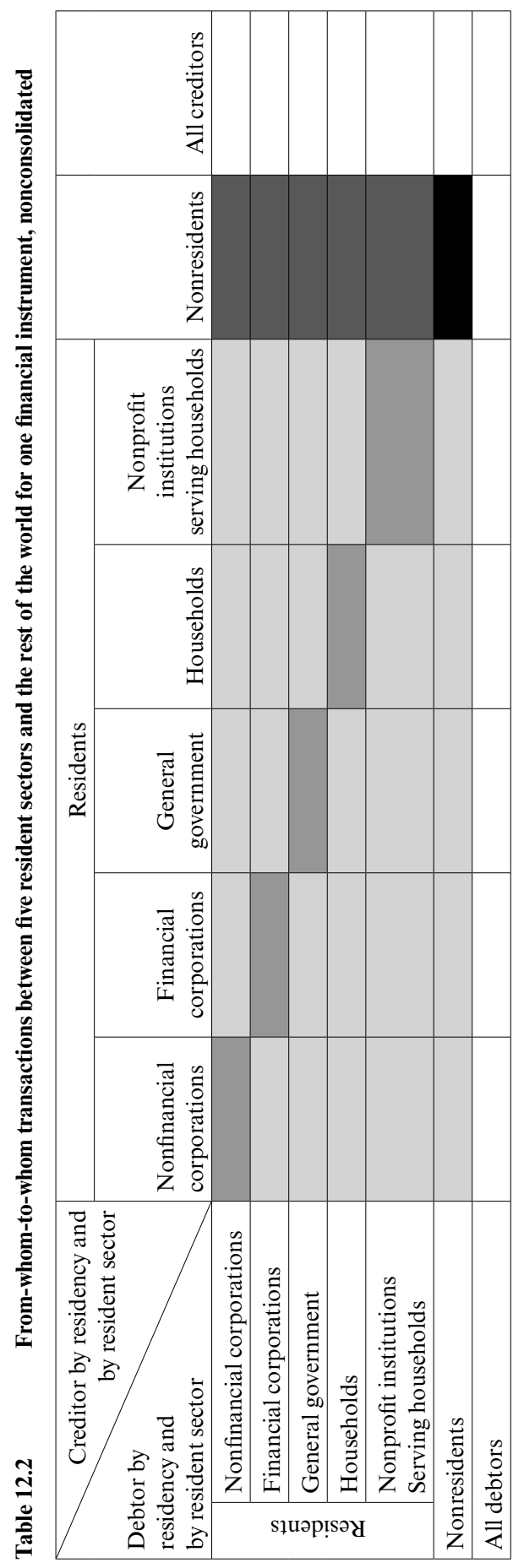


extension of the nonconsolidated financial balance sheet (again matching debtor and creditor sectors). Deriving the from-whom-to-whom financial account and balance sheet makes it also possible to draw up from-whom-towhom revaluation accounts and other changes in the volume of assets and liabilities by (sub)sector. The information on revaluations has substantive analytical value, as it allows quantifying the effects of asset price movements for a specific financial instrument by sector vis-à-vis other sectors as well as its effects on the net worth. Implementation of a complete set of sectoral financial positions and flows is challenging and may have to be prioritized in stages. Appendix $\mathrm{C}$ describes a possible sequencing of presentation formats from simple to more advanced counterparty details for sectoral financial positions and flows.

\subsection{Developments in Accounting on a From-Whom-to-Whom Basis}

\subsubsection{Experiences in the Compilation and Use of Flow of Funds}

Although official statistics for some countries, mainly advanced economies, disseminate data on financial positions and flows by institutional sectors, for the large majority of cases, information on a from-whom-to-whom basis is lacking. A review of data availability in G-20 economies recently conducted by the IMF's Statistics Department reveals that Australia disseminates financial transactions and positions with a breakdown by counterparties within an integrated framework. A few G-20 economies (Japan, the United States, and Canada) disseminate financial accounts and financial balance sheets with significant details for instruments and subsectors that make it possible to identify the debtor/creditor relationships in many cases, while some (France, Italy, Korea, and the United Kingdom) publish these data with some counterparty details. ${ }^{12}$

The Euro area accounts also show some detailed from-whom-to-whom data for loans and deposits. This also applies for the quarterly sectoral accounts compiled by many European countries (e.g., Austria, France, Germany, Italy, Portugal, Spain, and the United Kingdom). Some European countries (for example, Austria and Spain) publish full sectoral financial positions and transactions on a from-whom-to-whom basis.

Among the G-20 emerging market economies, some partial information (sectors and instruments) on the flow of funds (financial flows) on a fromwhom-to-whom basis is available for only a couple of countries. However, in many cases, partial information on financial positions and flows by sector and corresponding counterparty exists for financial institutions.

Some clarification of the term "flow of funds" would be useful. It is evi-

12. See Dawson (1996) for detailed elaboration of the compilation and use of US flow of funds. 
dent that the term "flow of funds" is used with different meanings among the data compilers and users. Sometimes the term is used to describe the financial transactions only, while in other cases flow of funds refer to both financial transactions and positions. Many countries use this term to compile data on resources and uses of funds for sectors of an economy. For example, Indonesia, Mexico, and South Africa, which compile the financial account by institutional sector, refer to these sectoral financial accounts as flow of funds. The United States refers to both the sectoral financial accounts and the balance sheets as the flow of funds accounts. Many countries (e.g., European countries) adhere strictly to the SNA terminology. In some instances, the flows in the flow of funds are derived as the difference between opening and closings positions, and thus, also include other economic flows (revaluations and changes in the volumes of assets and liabilities). In these cases, it would be conceptually wrong to use them for explaining net lending and borrowing.

A broad implementation of the from-whom-to-whom framework for financial positions and flows within an integrated framework of macroeconomic accounts has not yet been materialized. However, G-20 advanced economies seem to be in a good position to lead the development of these statistics by further extending the financial accounts and balance sheets already compiled and disseminated based on the SNA/European system of accounts (ESA) methodology. Reaching an agreement on harmonized terminology among countries is also necessary so as to avoid confusion.

\subsubsection{The Balance Sheet Approach}

The balance sheet approach (BSA) is an analytical framework for ascertaining how balance sheet weaknesses contribute to the origin and propagation of financial crisis. ${ }^{13}$ In addition to the traditional analysis of flows, the BSA focuses on the examination of stocks of assets and liabilities in a country's sectoral balance sheets. It starts with an analysis of sectoral vulnerabilities. Weaknesses of one sector can spill over to other sectors and can have an impact on the whole economy since financial difficulties of a debtor represent difficulties for its creditors. This approach of analyzing the origins and propagation of financial crisis has gained momentum since the financial crisis of the 1990s. In fact, the IMF has been involved in the development of data sources and using the BSA in its surveillance work. Table 12.3 shows a simplified version of the BSA matrix. As the liabilities in the BSA matrix are consolidated sectoral data, the matrix's diagonal (shaded boxes) of intrasectoral holdings remains empty.

In assessing balance sheet risks, the BSA framework considers four types of balance sheet mismatches that can trigger a financial crisis. These mismatches are (a) currency mismatches (liabilities in foreign currency and 
Table 12.3

A simplified BSA presentation of intersectoral positions of financial assets and liabilities

\begin{tabular}{|c|c|c|c|c|c|c|c|}
\hline & & $\begin{array}{c}\text { Holder of the } \\
\text { liability (creditor) }\end{array}$ & $\begin{array}{l}\text { Government } \\
\text { sector (incl. } \\
\text { central bank) }\end{array}$ & $\begin{array}{c}\text { Financial } \\
\text { sector }\end{array}$ & $\begin{array}{c}\text { Nonfinancial } \\
\text { Sector }\end{array}$ & $\begin{array}{c}\text { Rest of } \\
\text { the } \\
\text { world }\end{array}$ & Total \\
\hline Issuer & f the liab & ebtor) & & & & & \\
\hline Gov & ernment s & ncl. central bank) & & & & & \\
\hline Domes & ic curren & & & & & & \\
\hline Total o & her liabil & & & & & & \\
\hline short & term & & & & & & \\
\hline & foreign $\mathrm{cl}$ & & & & & & \\
\hline & domestic & & & & & & \\
\hline medi & Im and lo & & & & & & \\
\hline & foreign $\mathrm{cl}$ & & & & & & \\
\hline & domestic & & & & & & \\
\hline & & sector & & & & & \\
\hline Total li & abilities & & & & & & \\
\hline depo & its and o & rt term & & & & & \\
\hline & foreign $\mathrm{cl}$ & & & & & & \\
\hline & domestic & & & & & & \\
\hline medi & am and lo & & & & & & \\
\hline & foreign $\mathrm{cl}$ & & & & & & \\
\hline & domestic & & & & & & \\
\hline Equity & (capital) & & & & & & \\
\hline & Non & l sector & & & & & \\
\hline Total li & abilities & & & & & & \\
\hline short & term & & & & & & \\
\hline & foreign $\mathrm{cl}$ & & & & & & \\
\hline & domestic & & & & & & \\
\hline medi & um and lo & & & & & & \\
\hline & foreign $\mathrm{cl}$ & & & & & & \\
\hline & domestic & & & & & & \\
\hline Equity & (capital) & & & & & & \\
\hline & $\mathbf{R e}$ & world & & & & & \\
\hline है & Total lia & & & & & & \\
\hline गे & curre & short term & & & & & \\
\hline$\Xi \Xi$ & medi & long term & & & & & \\
\hline & Equity & & & & & & \\
\hline
\end{tabular}

Source: Allen et al. (2002) 
assets in domestic currency or vice versa-capital losses and default risk from devaluation or appreciation of exchange rate); (b) maturity mismatches (assets are long term and liabilities are short term causing risk of defaults associated with difficulties on debt rollover and increase in short-term interest rates); (c) capital structure mismatches (excessive reliance in debt instead of equity); and (d) solvency risk (assets not enough to cover liabilities).

The BSA refers to the SNA balance sheets but is limited to analyzing only positions (stocks) of financial assets and liabilities. It shows, for each financial instrument included, the sector incurring the liability (the debtor) and the sector acquiring the counterpart asset (the creditor). In other words, it corresponds to the "detailed flow of funds" in the SNA. The main source data for the compilation of the BSA are the Standardized Report Forms (SRFs) for monetary statistics reported monthly to the IMF's Statistics Department (STA). As of the end of 2012, thirty-one countries report data for all the subsectors of financial corporations (central banks, other depository corporations [ODCs] and other financial corporations [OFCs]). Reports covering only the central banks and the ODCs are received from 102 countries (including the countries in the Euro area). Other data sources for completing a BSA include the international investment position (IIP), the Coordinated Portfolio Investment Survey (CPIS), the Quarterly External Debt Statistics (QEDS), the Joint External Debt Hub (JEDH), and BIS's international banking statistics.

The sector breakdown of the BSA matrices consist of the central government, state and local government, financial sector and its subsectors, the nonfinancial corporations ( public and other), other resident sectors, and the rest of the world. The currency denominations and the maturity (original) breakdowns of assets and liabilities play an important role in the classification of assets and liabilities in the BSA. The classification of financial instruments by category follows the SNA but new breakdowns by subcategory are recommended, data availability of which are not always ensured.

\section{Compilation of the BSA}

The BSA matrices are compiled monthly for a selected number of countries based solely on the monetary statistics, although users can extend the coverage of the BSA using additional source data, usually available on a lower frequency. The main source data are the SRF reports received electronically by the IMF. Three different SRF reports are used to collect data, respectively, from (a) the central banks, (b) ODCs, and (c) OFCs. Data on financial assets and liabilities are collected for the main categories of financial instruments used in the SNA with a breakdown by currency (national and foreign currency) and sector. The standard sectors considered are the central bank, ODCs, OFCs, central government, state and local government, nonfinancial corporations (separate data for public and other nonfinancial corporations), other resident sectors (households and nonprofit 
institutions serving households), and nonresidents (rest of the world). These data provide satisfactory creditor/ debtor positions between the financial corporations subsectors and other sectors of the economy and the rest of the world.

In the monthly data, positions between government subsectors and the other resident sectors of the economy are incomplete because the creditor and debtor positions between general government, the nonfinancial corporations, and other resident sectors are not available on a monthly basis. The positions between general government and the rest of the world can be extracted from the IIP, the QEDS, and the CPIS, which are available at a lower frequency.

Data on positions between the nonfinancial corporations and other sectors of the economy are also incomplete, as data on the positions held by this sector against general government and other resident sectors are usually not available. Stocks of liabilities of the nonfinancial sector held as financial assets by the rest of the world are available from the IIP, the QEDS, and the $\mathrm{JEDH}$, while data on their holding of financial assets against the rest of the world are available from the IIP and the CPIS.

\subsubsection{The Coordinated Portfolio Investment Survey (CPIS)}

The purpose of the CPIS is to collect information on the stock of crossborder holdings of portfolio investment in securities (equity securities, and short- and long-term debt securities). ${ }^{14}$ The CPIS has been conducted annually since 2001 and collects data from about seventy-six countries on their year-end portfolio investment positions on the targeted financial instruments with a breakdown by country of issuer. The coverage of the CPIS corresponds to the coverage of the portfolio investment in the IIP. The concepts and principles underlying the CPIS are those contained in the sixth edition of the Balance of Payments and International Investment Position Manual (BPM6). ${ }^{15}$

The data collected permit the presentation at the level of each financial instrument on a from-whom-to-whom basis showing the countries that hold the assets vis-à-vis the issuer countries. The results of the survey show increases in the value of cross-border portfolio investment in most years.

The CPIS contains a number of encouraged items that are not reported by some countries. In particular, the CPIS contains several detailed splits of data, including on the domestic sector of holder of securities, and on the currency composition of the securities held. Thus, the CPIS identifies securities held by resident sectors with a breakdown of the resident holding sectors: monetary authorities, banks, other financial institutions (insurance corpora-

14. For the CPIS Guide, data, and metadata, please visit the IMF website at http://www.imf .org/external/np/sta/pi/cpis.htm.

15. See International Monetary Fund (2009). 
tions and pension funds, investment funds, and others), general government, and nonfinancial sector (nonfinancial corporations, households, and other). Data on portfolio investment liabilities by economy of nonresident holder are also reported.

In response to requests from data users, a number of enhancements to the CPIS are expected to be implemented starting with data for 2013. Such enhancements are expected to include increased frequency (i.e., semiannual CPIS data collections), timeliness (i.e., acceleration in the collection and redissemination of data), and scope. The increased scope covers collection of information, on a voluntary basis, on the sector of the issuer of securities; on short or negative positions; and data, on a from-whom-to-whom basis, on the domestic sector of holder vis-à-vis the sector of issuer for the twenty-five economies that are considered by the IMF to have systemically important financial sectors. ${ }^{16}$

\subsubsection{Coordinated Direct Investment Survey (CDIS)}

The IMF conducted a CDIS for the first time in 2009 and has been conducting the survey annually since then. ${ }^{17}$ Preliminary estimates of positions for a given year are released before end-December of the following year, and revised data are usually released six months later. Participation in the CDIS is voluntary and over ninety economies currently participate in the survey.

The purpose of the CDIS is to improve the quality of direct investment position statistics in the IIP and by immediate counterpart economy. Specifically, the objectives of the CDIS are to collect comprehensive and harmonized data, with geographic detail of counterpart country, on direct investment positions. The concepts, coverage, valuation, and classification of data collected in the CDIS are consistent with the BPM6 and the fourth edition of the OECD Benchmark Definition of Foreign Direct Investment.

The CDIS database presents detailed data on "inward" direct investment position (i.e., direct investment into the reporting economy) cross classified by economy of immediate investor, and data on "outward" direct investment position (i.e., direct investment abroad by the reporting economy) cross classified by economy of immediate investment. All participants in the CDIS provide data on their inward direct investment and most participants also provide data on their outward direct investment. The CDIS database is available publicly and contains breakdowns of direct investment position data

16. The IMF has made it mandatory for twenty-five jurisdictions with systemically important financial sectors to undergo financial stability assessments under the Financial Sector Assessment Program (FSAP) every five years. (http://www.imf.org/external/np/sec/pr/2010/pr10357 $. \mathrm{htm})$. These jurisdictions are Australia, Austria, Belgium, Brazil, Canada, China, France, Germany, Hong Kong SAR, India, Ireland, Italy, Japan, Luxembourg, Mexico, The Netherlands, Russian Federation, Singapore, South Korea, Spain, Sweden, Switzerland, Turkey, United Kingdom, and the United States.

17. For CDIS Guide, data, and metadata, please visit the IMF website at http://www.imf .org/external/np/sta/cdis/index.htm. 
including, in most instances, separate data on equity and debt positions, as well as tables that present "mirror" data (i.e., data on direct investment positions obtained from counterpart economies participating in the CDIS).

\subsubsection{BIS International Banking Statistics}

The BIS compiles quarterly data on gross balance sheet positions of banks in major banking centers against entities (banks and nonbanks) located in other countries worldwide. ${ }^{18}$ The statistics cover separate data on crossborder claims and liabilities in all currencies, and claims and liabilities visà-vis residents in foreign currency. ${ }^{19}$

Data are based on the residency and nonconsolidated concepts, consistently with the balance of payments and IIP statistics. There is, however, a deviation from these statistics in that the locational statistics also include banks' foreign currency positions vis-à-vis residents.

The locational international banking statistics provide information on international claims and liabilities for more than forty of the most important banking centers by country of residence of the counterparties, by major individual currencies, and sectors (only banks and nonbanks). Financial assets and liabilities are presented for three aggregated categories: (a) loans and deposits, (b) holdings and own issues of debt securities, and (c) other assets and liabilities. The latter two categories mainly cover portfolio and direct investment.

The statistics, aggregated at the country/financial center level, are reported by central banks and monetary authorities in the countries and financial centers that conduct large volumes of international lending and borrowing or deposit taking. The statistics provide a measure of the role of banks in intermediating international capital flows, a measure of the external debt owed to banks as reported from the creditor side, and a measure of the importance of financial centers and offshore banking activity.

The BIS and member central banks are strengthening the international banking statistics with more granular sectoral, instrument, and other breakdowns, with instruments and sectors consistent with national accounts defi-

18. For the locational international banking statistics guide and data, please visit the BIS website at http://www.bis.org/statistics/bankstats.htm.

19. The BIS also collects and publishes consolidated banking statistics on banks' on-balance sheet financial claims on the rest of the world. The quarterly data cover contractual lending by the head office and all its branches and subsidiaries on a worldwide consolidated basis, that is, net of interoffice accounts. Total claims are broken down by remaining maturity, sector (banks, nonbank private sector, and public sector), as well as vis-à-vis country. Two sets of statistics are compiled. The first set collects data on an immediate borrower basis, that is, claims are attributed to the country where the original risk lies. The second set collects data on an ultimate risk basis; that is, claims are attributed to the country where the final risk lies. Currently, central banks in thirty countries report their aggregate national consolidated data to the BIS, which uses them as the basis for calculating and publishing global data. For more information, please visit the BIS website at http://www.bis.org/statistics/consstats.htm. 
nitions. The enhancements are expected to be reflected in the BIS data over the coming few years, and, inter alia, should support efforts to better monitor maturity and currency mismatches among international banks.

\subsubsection{Security-by-Security Statistics}

Globalization, financial innovation, and dynamic changes in the structures, interconnectedness, and responses of financial markets have led to a higher demand for more detailed, timely, and harmonized securities statistics that make it possible for users and policymakers to respond quickly to, or even anticipate, financial market developments. These requirements may increasingly be met by moving gradually to innovative statistical compilation systems that are based on collection of highly granular data at individual security level. The underlying idea is that such data can be arranged and aggregated by statistics compilers in a highly flexible manner to meet changing needs in statistical indicators, rather than relying on systems that use processed and aggregated data and, thus, are not flexible enough for deriving, as needs arise, indicators that the underlying data system is capable to produce. Modern information technology provides a sufficient technical support for handling large microdatabases.

Securities statistics are particularly suited to this approach as the majority of securities have a unique identifier and many of the analytically relevant information on securities issues and holdings may be obtained from commercial sources. Such data complemented with additional direct and indirect data sources can be aggregated and consolidated within a reference securities database. The development of a single reference securities database in the European System of Central Banks - the Centralized Securities Database (CSDB) - is the cornerstone of the transition to security-by-security-based securities statistics in Europe. The development of the CSDB is described below under the subsection on Euro area accounts.

More importantly, strengthening of securities statistics is relevant to the improvement of many domains of macroeconomic statistics. Not surprisingly, many countries have started to develop a security-by-security database, which is an important pillar for developing sectoral financial positions and flows in a from-whom-to-whom framework. The focus of the international community has been on providing clear international methodological guidance on compiling securities data, through the Handbook on Securities Statistics and on making data more readily available through the BIS. ${ }^{20} \mathrm{It}$ has strengthened the collection and dissemination of securities data. The number of central banks reporting data has risen to about sixty, including virtually all G-20 members, as of the end of $2012 .{ }^{21}$ 


\subsubsection{Euro Area Accounts on a From-Whom-to-Whom Basis}

The ECB has been publishing, since June 2007, the quarterly integrated Euro area accounts for institutional sectors (the Euro area accounts or EAA). These data are produced in collaboration with the national central banks, Eurostat and the national statistical institutes, and start in the first quarter of 1999. The data become available approximately four months after the end of the reference quarter. The Euro area accounts provide consistent and comprehensive information on macroeconomic developments, both for the economy as a whole and by institutional sectors (nonfinancial corporations, financial corporations, government, and households). They encompass integrated nonfinancial and financial accounts, including balance sheets.

In addition, the ECB prepares and makes analytical use of financial positions and flows on a from-whom-to-whom basis (by debtor/creditor) for euro area aggregates. The development and use of the financial data on a from-whom-to-whom framework are limited, but are expanding as efforts are being made at the country and regional levels to improve such statistics. Four main areas of such data framework developed and used by the ECB are noteworthy. They are (a) deposits and loans on a from-whom-to-whom basis, (b) monetary aggregates and their counterparties, (c) general government debt, and (d) securities issues and holdings. A brief description these initiatives are given below. ${ }^{22}$

\section{Deposits and Loans on a From-Whom-to-Whom Basis}

The ECB compiles, only at the Euro-area level, outstanding amounts and transactions for deposits, short-term loans and long-term loans by counterpart sector. Cross-sectional tables provide an overview of the activities between the various sectors of the Euro-area economy in the latest available period, whereas the time series show detail from a time perspective. These data are available on a quarterly basis at the ECB's website.

\section{Monitoring Monetary Transmission Processes by Integrating Money in a From-Whom-to-Whom Framework}

The integration of monetary aggregates and its counterparts in a fromwhom-to-whom framework is derived from the consolidated financial transactions and balance sheets of the resident money-issuing sector visà-vis the resident money-holding sectors. An initial set of source data available are the balance sheets of monetary financial institutions (MFI) from which monetary aggregates and the main counterparts to broad money are to be calculated. These balance sheet statistics comprise often rather

22. See ECB, Monthly Bulletin, various issues and statistical section for more information. 
detailed breakdowns of various financial instruments, such as deposits, loans, and debt securities by maturity and counterpart sector. Balance of payment statistics and statistics on securities issuance by general government and by financial and nonfinancial corporations complement this data set.

The corresponding financial accounts and balance sheets derived from these source data, with a breakdown of the financial corporations sector, of the financial asset and liability categories, and of the counterparts, allow the identification of broad money. A simple example of integrating money and credit in a from-whom-to-whom framework is presented in appendix A.

The money-issuing sector is assumed to consist of the central bank, resident deposit-taking corporations, and resident money market funds, together comprising the MFI subsector. Money holders are the remaining resident sectors, including the remaining subsectors in the financial corporations sector and all subsectors of general government. (This is a simplification -in reality, central government may have monetary liabilities, and its holdings of monetary instruments issued by MFIs may be excluded from the monetary aggregates.) Holdings of money by the money-issuing sector itself are consolidated. The rest of the world sector is assumed to be money neutral; that is, neither the liabilities of nonresidents, nor nonresidents' holdings of money issued by resident money issuers, are counted in money.

Monetary variables are considered to comprise (a) currency (issued by the central bank); (b) transferable deposits held with MFIs; (c) deposits redeemable at a period of notice of up to and including three months (i.e., short-term savings deposits) held with MFIs; (d) deposits with an agreed maturity of up to and including two years (i.e., short-term time deposits) held with MFIs; and (e) repurchase agreements, money market fund shares or units, and debt securities with an original maturity of up to and including two years issued by MFIs. These monetary variables may also cover structured securities and structured deposits. Depending on the coverage, various monetary aggregates may be derived.

\section{Monitoring Government Debt in a From-Whom-to-Whom Framework}

Data on general government gross debt are used to monitor fiscal developments within the Euro area. General government gross debt or Maastricht debt excludes, as gross consolidated debt, any government debt held as a financial asset by government units. It comprises the financial instruments currency and deposits, debt securities, and loans.

Maastricht debt provides debt data with a breakdown by holder or creditor. They are split into debt held by residents of an economy within the Euro area or within the European Union and by nonresident holders. Holdings of debt by residents are calculated as the sum of the debt held by the central bank, other monetary financial institutions, other financial institutions, and 
other residents. In addition to their breakdown by instrument and holder, debt is also presented by original and residual maturities and by currency of denomination.

\section{Monitoring Securities Issues and Holdings in a From-Whom-to-Whom Framework}

The from-whom-to-whom framework allows for a detailed presentation of financing and financial investment via securities, which the ECB uses for a number of purposes, especially in the context of monetary policy and financial stability analysis. It sheds light on the sectoral compositions of assets and liabilities, and on potential strengths and vulnerabilities in portfolios.

The complexity of from-whom-to-whom tables for securities is determined by the detail of the breakdowns chosen for securities (by subcategory) and for the creditors and debtors (by residency, sector, and subsector). Combining these breakdowns leads to a rather large number of from-whom-towhom relationships, especially as the data may need to be presented for both positions and flows. Accordingly, a selection by security subcategory, sector, and subsector is essential.

At the ECB, a centralized security-by-security database (CSDB) has been set up by the European System of Central Banks (ESCB) to further improve the quality of position and flow data on securities. The CSDB is a microdatabase that stores information on individual securities, from which statistics can be compiled flexibly to serve diverse needs. The CSDB covers various categories of financial instruments, such as debt securities, equity securities, and investment fund shares or units. Information stored on an instrument is broken down into attributes that describe selected characteristics of the instrument. The selection of attributes may vary depending on the purpose of the database. Attributes useful for statistical applications include the international securities identification number (ISIN), name of the issuer, residence of the issuer, the sector and subsector of issuer, issue date, redemption date, the type of security, the currency of denomination, the issue price, the redemption price, the outstanding amount or the market capitalization, and the coupon payments and dates.

The production of statistics from the CSDB can be presented as a threestage process. First, it involves inputs by collecting and purchasing data on individual securities from a range of sources, such as central banks, government agencies, commercial data providers and securities exchanges (in their capacity as custodians). Second, it covers data quality management. The individual security data collected from different sources are received into the database, merged, and stored. Checks for completeness, plausibility, and consistency are then performed, and where errors are detected, observations are corrected. Third, it involves the storing of individual security data according to various classification criteria.

There is a project ongoing to link the CSDB dealing with securities issues 
statistics to securities holdings statistics for resident holders grouped by sector and subsector, as well as for nonresident holders. For this purpose, information provided by respondents (as holders or custodians) is linked at the individual security level to the data stored in the CSDB. The link is often made using the ISIN, but also referring to information on the debt securities holders and holdings: (a) the holder by residency and institutional sector and subsector and also by large and complex financial or nonfinancial group; and (b) the amount of holdings in currency.

Current reporting schemes on securities holdings are mainly based on two groups of agents having access to such type of information: (a) custodians (as well as centralized securities depositories); and (b) direct reporters. In most cases, data are collected from custodians on a security-by-security basis. This also refers to the collection of data on the securities holdings of residents from nonresident custodians to allow the breakdown of holdings by the residency of the issuer to be derived. Direct reporters provide security-by-security data on their holdings with various breakdowns: by type of instrument, maturity, residence of issuer, and so forth.

Establishing an integrated compilation framework for securities issues and securities holdings statistics, which provides timely and high-frequency data with breakdowns by type of financial instrument, currency denomination, maturity, issuing country, and sector or subsector is rather demanding and cost intensive. Accordingly, the ESCB has agreed that it will still take a few years to use it for the regular production of securities statistics, starting with financial balance sheet data.

\subsection{Implementation of the Sectoral Accounts, Balance Sheets, and Flow of Funds}

For residency-based macroeconomic statistics, the SNA serves as the integrated statistical framework for producing a consistent set of macroeconomic and financial statistics, including sectoral financial positions and flows on a from-whom-to-whom basis. This section, therefore, discusses the implementation of the broader sectoral accounts and balance sheets within the SNA framework.

Although the SNA, with its latest 2008 version, provides the statistical framework for compiling integrated sectoral accounts, balance sheets, and flow of funds, the framework has not been fully utilized in practice to compile and disseminate these accounts in a fully integrated and comprehensive way. Past efforts in statistical development made good progress in certain domains of macroeconomic statistics. Significant amounts of information is available in some specific areas. For example, detailed monetary and financial statistics are available for depository financial corporations. Other balance sheet data where progress has been made include external debt, international reserves, international investment positions, and coordinated cross-border 
portfolio and direct investment. Detailed financial information may be available for the government sector and subsectors ( particularly for many OECD countries), and initiatives have been taken to better cover financial balance sheets of the household sector and nonbank financial institutions. However, serious data gaps exist for specific sectors such as the nonfinancial corporations or for specific areas such as the stocks and flows of nonfinancial assets, particularly the nonproduced nonfinancial assets. A status on the availability of sectoral balance sheets and accumulations accounts in the G-20 economies as of the end of 2012 is presented in appendix B.

One important aspect that hampered analytical work and policy evaluation at the regional and multilateral levels at the wake of the 2008 global crisis was the lack of international comparability of disseminated sectoral national accounts. Not only the implementation of the SNA by countries was uneven in terms of the scope of the accounts disseminated, but also classifications used to disseminate national data differ across countries. As a result, international comparability could be ascertained only at a higher level of aggregation, reducing the usefulness of these data. It should be noted that Eurostat and ECB made substantial contribution to the harmonization of sectoral accounts within the European Union. However, the 2008 global crisis revealed that stronger and well-coordinated international efforts are needed to ensure the development and dissemination of internationally comparable sectoral accounts, balance sheets, and flow of funds.

With the objective of seeking consensus on the strategy for expanding the scope of internationally comparable sectoral accounts and balance sheets, the IMF and OECD, in collaboration with other members of the IAG, organized a conference, "Strengthening Sectoral Position and Flow Data in the Macroeconomic Accounts," from February 28 to March 2, 2011, at IMF Headquarters. ${ }^{23}$ The conference (a) provided guidance toward a minimum and encouraged set of internationally comparable sectoral accounts and balance sheets; (b) discussed priorities, time frame, and way forward; (c) reached common understanding on the international collaboration for data collection and dissemination by international organizations; and (d) deliberated on the outreach, training, and technical assistance programs for supporting the implementation.

An important milestone in taking forward the work on implementing sectoral accounts and balance sheets is the development of templates for a minimum and encouraged set of internationally comparable sectoral accounts and balance sheets arrived at through a global consultative process led by the IMF. The process went through the various stages as follows:

- In early 2010, the IMF assessed the overall availability and current practices in the dissemination of sectoral accounts and balance sheets in G-20 economies and non-G-20 advanced economies.

23. The papers presented at the conference and the summary report are available at http:// www.imf.org/external/np/seminars/eng/2011/sta/index.htm. 
- A joint IMF-OECD conference provided guidance toward the development of the templates.

- An IAG working group, in consultation with various stakeholders, including several countries, finalized the templates in May 2012. The templates are available from the IMF's website (http://www.imf.org /external/np/sta/templates/sectacct/index.htm) and from the SNA website (http://unstats.un.org/unsd/nationalaccount/imp.asp) hosted by the United Nations Statistics Division (UNSD).

- In addition, the templates, at various stages of development, were discussed at the conference of G-20 senior officials on the G-20 Data Gaps Initiative at the IMF Headquarters in Washington, DC, from March 30 to 31, 2011; at the joint session of the OECD Working Party on Financial Statistics and the OECD Working Party on National Accounts in Paris from October 24 to 28, 2011; and at the meeting of the Advisory Expert Group on National Accounts in New York from April 21 to 23, 2012.

The templates set the scope of sectoral accounts and balance sheets and provide a basis for internationally coordinated efforts toward producing and disseminating internationally comparable sectoral accounts. The templates include guidance for classifications in four building blocks: (a) minimum and encouraged sector and subsector breakdowns; (b) transactions breakdowns in nonfinancial (current and capital) accounts; (c) classification of financial instruments (including debt on remaining maturity and currency composition); and (d) classification of nonfinancial assets. While the nonfinancial accounts and the stocks and transactions of financial assets and liabilities are to be compiled on a quarterly basis (with a quarterly timeliness), the stocks of nonfinancial assets are to be compiled on an annual basis (with nine-month timeliness). Appendix D shows the framework for minimum and encouraged classifications for the templates for quarterly current and capital accounts (appendix table 12D.1), for quarterly stocks and transactions of financial assets and liabilities (appendix table 12D.2), and for annual stocks of nonfinancial assets (appendix table 12D.3).

The relevant international organizations started to follow up on these recommendations in a coordinated fashion. As far as possible, the work on sectoral accounts is integrated with the implementation of the 2008 SNA. As part of the 2008 SNA implementation, important issues are discussed and guidance is provided by the Intersecretariat Working Group on National Accounts (ISWGNA) and its Advisory Expert Group on National Accounts. ${ }^{24}$ It is anticipated that G-20 economies would compile statistics according to these templates as part of their broader plans for implementing the 2008 SNA. An economy may aim for greater detail than the minimum

24. The deliberations of the ISWGNA and AEG on the 2008 SNA implementation can be found at the United Nations Statistics Division's website (http://unstats.un.org/unsd/national account/iswgna.asp). 
requirements established in the templates, including flow of funds (both financial positions and flows) on a from-whom-to-whom basis, depending on analytical and policy requirements.

To support the compilation of sectoral accounts and balance sheets, the IMF has initiated a series of bilateral consultations with G-20 and some nonG-20 countries and started to organize seminars for IMF member countries. Similarly, OECD, ECB, and Eurostat have intensified their outreach and consultations with their member states. Further, under the auspices of the IAG, currently available sectoral accounts data for the G-20 economies, primarily sourced from the OECD, and Eurostat and European Central Bank within Europe, are available on the Principal Global Indicators website. ${ }^{25}$

It should be noted that countries are at different stages of development of integrated sectoral accounts, and hence, the implementation will have different implications in terms of resources and institutional setup in different countries. Designing and implementing changes to or initiating new data collection systems are costly and priorities must therefore be established among the various potential improvements. A thorough assessment of the feasibility and resource requirements for implementing each element of the templates should be conducted. Country experiences show that the development of integrated sectoral accounts requires an active and close coordination among the various data producing agencies. Ultimately, requirements for analytical and policy purposes should guide the priorities for sectoral accounts, balance sheets, and flow of funds. For example, timeliness of sectoral accounts is highly important.

The priorities should be time bound as time frame determines the scope of data development that is feasible within a given resource constraint. There is an understanding among the stakeholders (international agencies and countries) that the initial stage of the sectoral accounts project should be implemented by 2014. Many countries (mostly advanced economies) are working toward implementing the 2008 SNA by $2014 .{ }^{26}$ This is a good opportunity to incorporate proposals arising from the DGI work on sectoral accounts into the 2008 SNA implementation plans of countries.

Based on country experiences and the discussion at the IMF-OECD conference, some guidance on the priorities for strengthening sectoral accounts is evident. Initial focus should be given to the minimum set of internationally comparable sectoral accounts and balance sheets. Countries should then work on expanding the breakdowns for sectors (particularly for financial sector), financial instruments, and nonfinancial assets. Finally, the compilation of financial positions and flows on a from-whom-to-whom basis should be given priority in the medium term (probably after the initial stage mentioned in the previous paragraph). Such prioritization will allow countries

25. http://www.principalglobalindicators.org/default.aspx.

26. Australia, Canada, and the United States implemented and disseminated national accounts statistics according to the 2008 SNA in 2009, 2012, and 2013, respectively. 
with different levels of development in the sectoral accounts to make progress. While the minimum set will serve as a benchmark for countries with no or partial sectoral accounts, countries with sufficient sectoral accounts can move toward implementing the fully integrated sectoral accounts and the compilation of financial positions and flows on a from-whom-to-whom basis.

It was recognized that for countries that do not yet compile sectoral accounts, the development of such statistics will require addressing large data gaps in their existing statistical systems. There is a need to study carefully the requirements, resource implications, institutional issues, reporting burden, and confidentiality issues before designing necessary surveys to collect data. Countries should evaluate what can be achieved by integrating and using available statistics. For countries that do not yet compile sectoral accounts, there is an advantage in making a quick start with sectors for which a significant amount of data is or may be made available (most likely, financial corporations and general government).

Appropriate funding for outreach, technical assistance, and training will be needed to support activities at the country and international levels. International organizations and donors will need to draw on their resources to adequately finance these activities. A two-track approach is needed to assist countries depending on whether a country has an advanced or good statistical system (most of the advanced economies) or it has a less developed statistical system (most of the emerging market economies). While outreach programs (workshops to discuss compilation issues) might be sufficient to assist the first group of countries, technical assistance and training programs will be needed to assist the second group of countries to implement the sectoral accounts initiative. International cooperation and some division of responsibilities among the international agencies might be necessary.

One important aspect of the sectoral accounts initiative is to enhance collaboration among the international organizations for collecting, sharing, and disseminating sectoral accounts. The main principle is that a country should be required to complete the templates for a given reference period or date and submit data to only one international organization. This will reduce burdens on countries and will avoid dissemination of conflicting data (for example, due to different vintages of data or timeliness of data capture) by international organizations.

\subsection{Applying the From-Whom-to-Whom Framework for Financial Positions and Flows}

\subsubsection{Collecting and Compiling Data on a From-Whom-to-Whom Basis}

A set of accounts that show by sector and type of financial instrument the transactions, other economic flows, and the positions of financial assets and 
liabilities vis-à-vis the counterpart sector, whether resident or cross border, reflect more accurately the reality of the interconnected domestic and global economy and provide more useful information for opportunely dealing with the financial positions and flows that can originate in a crisis.

Especially in the context of requirements related to multilateral surveillance, financial stability, and policy coordination, sectoral accounts on a from-whom-to-whom basis are a powerful tool to provide comparable data for G-20 as well as other economies. Such indicators reflecting imbalances may cover data on the current account derived consistently from the rest of the world, data on deficit and debt derived from general government, or data on private savings, and debt derived from the nonfinancial corporations and household sector accounts. Especially important is the ability to analyze sectoral imbalances in connection with sectoral real and financial linkages.

Transactions on a from-whom-to-whom basis permit understanding of how surpluses by one sector are allocated among different financial instruments and sectors and cross border, or how sectors with deficits meet their financial needs in terms of financial instruments used and sectors providing it, including the rest of the world. They also reflect the increasing activities in the financial markets for the sake of financial returns and speculative gains. No less important is identifying changes in balance sheets that result from revaluations and other changes like mergers and acquisitions. The greater subsector details proposed for the financial sector will augment the ability to understand and monitor relationships and dynamics between banks and nonbanks. The framework also allows to assess the effects of asset prices on sectoral net worth and to identify sectors that are affected by changes in prices of a certain asset class.

The compilation of the SNA accounts for financial positions and flows on a from-whom-to-whom basis will fill some important data gaps in the currently available macroeconomic statistics. This, however, requires further investments in new data collection systems as described above for securities databases. As discussed in the previous section, the collection of more detailed data from markets and institutional sectors has to be weighed against the response burden to the statistical units, confidentiality constraints, and the cost of collecting and processing the additional source data. As a result, compromises need to be established in the level of aggregation of the data to be collected as well as of the data sources to be used.

Without discussing specific issues in detail, some main areas that need to be addressed, while designing work plans for developing integrated sectoral accounts (including sectoral financial positions and flows on a from-whomto-whom basis), should include the following: (a) allocation of responsibilities, (b) resources (staffing, financing, and information technology), (c) coordination and cooperation, (d) data and metadata dissemination, and (e) data transmission to international organizations. At the planning stage for the 
implementation of the work, countries should also have consultations with prospective users of the data.

The compilation of the integrated financial positions and flows on a fromwhom-to-whom-basis has implications for the internal allocation of responsibilities within each country. The division of work among different institutions depends on a country's specific institutional arrangements for the compilation of the integrated national accounts statistics. Different agencies may be involved, each responsible for a specific part of the accounts in close interaction, thus ensuring full coverage and assuring consistency. Roles, responsibilities, and coordination mechanisms must be ensured through explicit and formal mechanisms.

Compilation of the financial positions and flows on a from-whom-to whom-basis will require more resources even for those countries that already produce financial account and balance sheets. There is additional work in data collection and processing, and the verification and validation of the data to ensure consistency across sectors on debtor/creditor positions by type of financial instrument requires close working relations among all agencies involved at different stages of compilation. Agreements have to be reached on a timetable for interagency submission of data and for releasing the final products, including the transmission of the information to international organizations.

The work on integrated sectoral accounts and balance sheets will facilitate the coordination of work on different macroeconomic statistics domains and promote their consistency at the level of data collection and compilation. This work could bring efficiencies. Such an approach will have implications for each agency's work as future work on various macroeconomic statistics domains will need to be coordinated. The sectoral accounts and balance sheets may, in fact, be used as the main framework for conducting the work on cross-sectoral data consistency on a more systematic and regular basis.

\subsubsection{Phases in Implementing the From-Whom-to-Whom Data}

As a condition for assuring international comparability, the accounts on financial positions and flows should be compiled and disseminated using the minimum and encouraged set of categories of assets/liabilities and institutional sectors as agreed on for the templates. Depending on their own analytical needs and data availability, countries may compile the data at more disaggregated levels reflecting their own institutional settings or for particular financial instruments.

Considering the difficulties that countries are likely to face in compiling exhaustive accounts, implementation could occur in phases. First, the accounts for the main institutional sectors by financial instrument category are likely to be implemented. With the development of data sources a further breakdown of the financial corporations' accounts by subsector may follow. In a further phase, from-whom-to-whom data may be collected and 
compiled for selected financial instruments, such as loans, deposits, or insurance and pension entitlements. Most challenging will be to provide such detailed data for securities and other negotiable financial instruments due to secondary market transactions. Due to data confidentiality, the collection of sectoral financial positions and flows on a from-whom-to-whom basis may be sometimes more problematic than simply collecting data on assets and liabilities without counterparty details, particularly when higher level of details is requested.

Not every country may need to follow the same path for developing sectoral financial positions and flows. There is no single sequence of stages that may be applicable in all cases. Country experiences suggest that the following phases may provide some guidelines:

traditional financial transactions and positions by main sectors; further details for financial corporations by subsectors and for general government, other economic flows may also be considered;

from-whom-to-whom financial positions and flows for subsectors of financial corporations and possibly general government;

from-whom-to-whom financial positions and flows for specific instruments (loans, deposits, some important negotiable instruments); and

fully integrated financial positions and flows on a from-whom-to-whom basis by sectors (subsectors) - starting from aggregated subsector and instrument details toward more disaggregated subsector and instrument details.

Technical assistance and training will be required particularly for those countries that have not yet implemented complete sectoral accounts. Training may adopt a regional format, thus maximizing the benefits of the resources used. Given existing resource constraints for technical assistance, an implementation based on selected pilot countries may be necessary. Existing international forums (such as the ISWGNA, OECD working parties on financial accounts and national accounts, and activities of the ECB and Eurostat) will be used to provide methodological support in the implementation of sectoral accounts and balance sheets. The IMF has held bilateral discussions with the Russian Federation, South Africa, Indonesia, and Thailand during 2011 and 2012 and is expanding the coverage of countries in the years to come. These countries have designed work programs to develop and disseminate sectoral accounts and balance sheets (Russian Federation by 2016, South Africa by 2014, Indonesia by 2015 , and Thailand by 2014). Although the goal by these dates is to disseminate traditional sectoral accounts and balance sheets (without from-whom-to-whom details), the compilation system for developing the quarterly sectoral financial positions and flows is built, in principle, using the from-whom-to-whom framework. This will allow countries to publish partial from-whom-to-whom financial positions and flows 
and will set the stage for development of quarterly financial positions and flows on a from-whom-to-whom basis in the medium term.

As a first step, the presentation of sectoral financial positions and flows can follow simplified tables showing creditors' flows and positions by residency of debtors and by financial instruments (and a similar table for debtors' financial positions and flows). At a later stage, tables showing fromwhom-to-whom data can be compiled. Appendix tables 12C.1 and 12C.2 in appendix $\mathrm{C}$ provide some guidance for applying such an approach.

\subsection{Concluding Remarks}

This chapter sets the background for promoting internationally coordinated efforts for compiling and disseminating data on sectoral financial positions and flows on a from-whom-to-whom basis within the integrated macroeconomic statistics framework, such as the SNA. The compilation of these data would fill a serious data gap as revealed by the global crisis of 2008: information shedding light on the financial interconnectedness among the various sectors of an economy and between them and their counterparties in the rest of the world.

The chapter elaborates the main attributes of the integrated macroeconomic accounts of the 2008 SNA, which allows it to serve as the framework for compiling sectoral accounts and balance sheets, including sectoral financial positions and flows on a from-whom-to-whom-basis. In particular, the SNA integrated framework ensures four consistency rules as follows: (a) vertical consistency (total of all debit entries and that of all credit entries of an institutional unit [sector] are equal); (b) horizontal consistency (debit entries of a transaction type for all units are equal to the credit entries of that transaction type for all units); (c) counterpart consistency (an entry arising from an exchange has a counterpart entry of the same value and at the same time in the account of the counterparty); and (d) stock-flow consistency (changes between opening and closing stocks are fully accounted in transactions, other volume changes, and revaluations). The core accounting structure of the 2008 SNA for financial positions and flows focuses on showing who does what rather than who does what with whom. This chapter recommends that prominence be given in the SNA to the from-whom-towhom basis as the main underlying principle for compiling and disseminating sectoral financial positions and flows.

The advantage of using sectoral accounts and balance sheets that are compiled within the integrated SNA framework, contrary to using fragmentary data from different sources, is that such framework ensures data consistency for all entities and for all economic flows and positions, and thus allows for a systematic understanding of the relationships between economic flows in the real and the financial spheres, financial interconnect- 
edness, and linkages among the various economic functions (e.g., between production, consumption, savings, and accumulation).

However, the 2008 global crisis revealed that stronger and well-coordinated international efforts are needed to ensure the development and dissemination of internationally comparable sectoral accounts, balance sheets, and flow of funds. An important milestone in taking forward the work on implementing sectoral accounts and balance sheets is the development of templates for a minimum and encouraged set of internationally comparable sectoral accounts and balance sheets. The templates provide guidance for developing plans for implementation, benchmarks for monitoring progress, and a yardstick for ensuring international comparability. Existing international forums will need to be used more effectively to provide methodological support in the implementation of sectoral accounts and balance sheets. Appropriate funding for outreach, technical assistance, and training will be needed to support activities at the country and international levels.

The current situation on the availability of data on financial positions and flows on a from-whom-to-whom basis is at an early stage. Given the importance to fill these data gaps, compiling and disseminating the accounts on sectoral financial positions and flows using the templates is a condition for achieving international comparability.

The chapter highlights some main areas that need to be addressed when designing work plans and setting up priorities for developing integrated sectoral accounts and balance sheets. Many advanced economies and several emerging market economies are already in the process of enhancing or developing the accounts in accordance with the agreed templates and in the context of their plans for the implementation of the 2008 SNA. Lessons learned from this exercise would be useful not only for other countries that will develop sectoral accounts in the future, but also to identify best practices to enhance the quality of data being compiled now.

The fully integrated SNA sectoral accounts and balance sheets would also improve the integration of scattered information and highlight the inconsistencies between the data sets of the various macroeconomic domains as it ensures a holistic approach to all sectors of an economy and rest of the world. The sectoral accounts will provide an integration framework for macroeconomic data on external, fiscal, and financial sectors with those of the rest of the economy. At the country level, this will facilitate the coordination of work on different macroeconomic statistics domains and promote their consistency at the data collection and compilation stages, thus eliminating or significantly reducing inconsistency of disseminated data.

The ongoing international initiative to improve collaboration among the international organizations for collecting, sharing, and disseminating sectoral accounts and balance sheets is commendable. This initiative should be given priority so that a mechanism is in place before many of the advanced economies and a few emerging market economies start producing these data 
in 2014. This will not only reduce burdens on countries, but enhance the usefulness of data for users and avoid confusions as all sources will be disseminating the same set of data on sectoral accounts and balance sheets.

\section{Appendix A}

\section{Integrating Money and Credit in a From-Whom-to-Whom Framework}

There are practical challenges that may have to be tackled when integrating money into the framework for financial positions and flows on a fromwhom-to-whom basis. The definitions of money and of money-issuing, money-holding, and money-neutral sectors are not necessarily based on the classification of financial assets and institutional sectors described in section 12.3. Maturity thresholds, valuation methods, and recording principles for accrued interest in monetary statistics generally coincide with those recommended for use in the SNA.

Appendix table 12A.1 shows in italics the money holders' financial transactions in assets, which represent monetary claims on the money-issuing sector (resident MFIs). The outstanding money stock may be identified in a similar way in the financial balance sheet.

In appendix table 12A.2, credit as the counterpart to money is shown. The credit counterpart reveals how the change in money is related to lending by money issuers (MFIs) to other residents in all forms, including by the acquisition of securities issued by MFIs. This counterpart comprises part of the assets of the money-issuing sector.

Another part of the assets of the money-issuing sector, net of liabilities to nonresidents, constitutes the external counterpart, the net external assets of the money-issuing sector (in balance sheet terms), or changes in them (corresponding to transactions in the financial account).

The transactions and positions of the rest of the world correspond (after some rearrangements) to the balance of payments and IIP. Net external assets of MFIs, summarizing the money-issuing sector's transactions with the rest of the world, link to money through the MFI accounting framework. The balance of payments identity may then be exploited to show how the money-holding sectors' transactions with the rest of the world relate to changes in money, since the money issuers' balance of payments transactions must equal all other resident sectors' balance of payments transactions with reverse sign (for this purpose it is desirable that errors and omissions in the balance of payments have been eliminated when compiling the sector accounts and balance sheets; otherwise, they may be attributed to the money-holding sectors). 


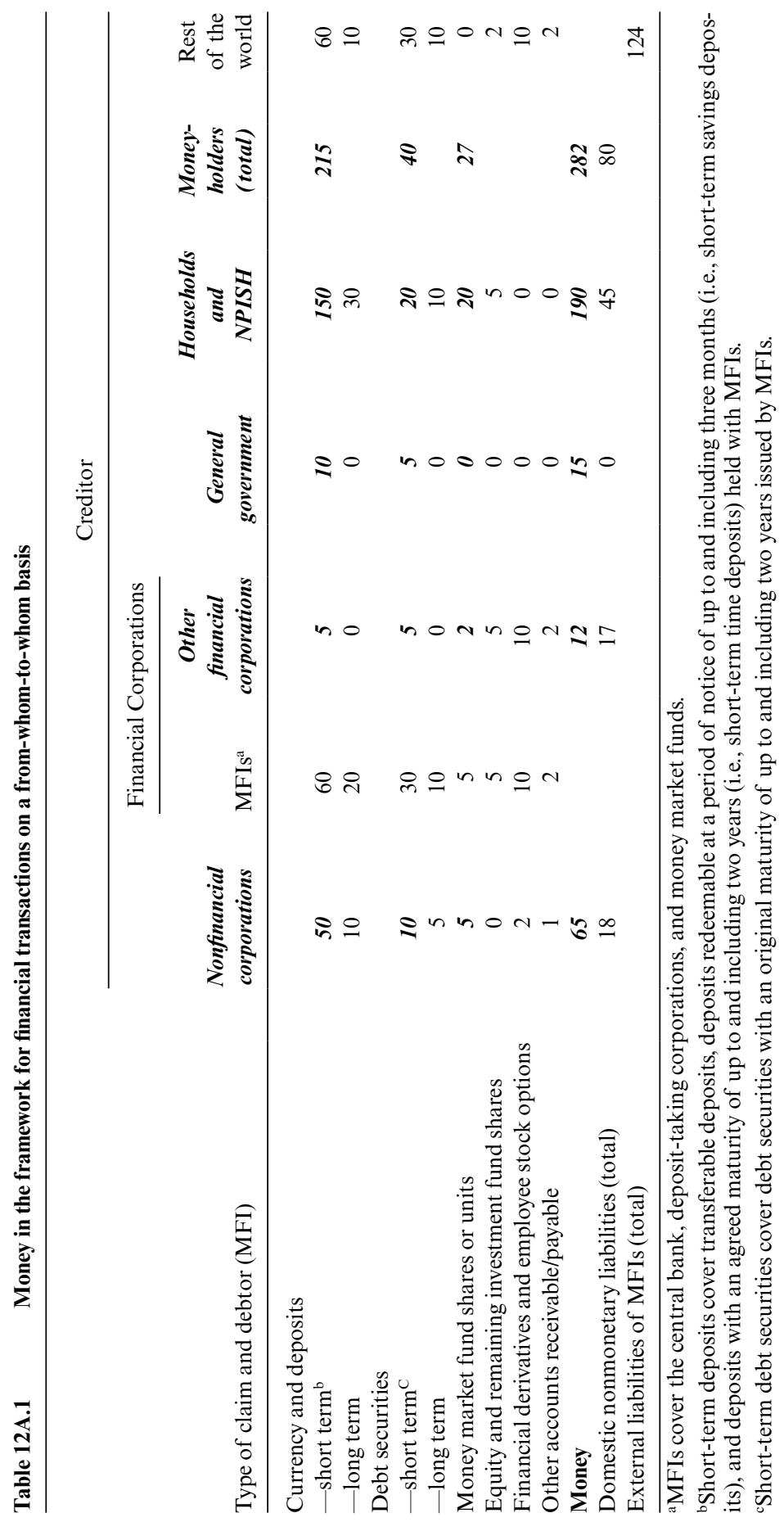




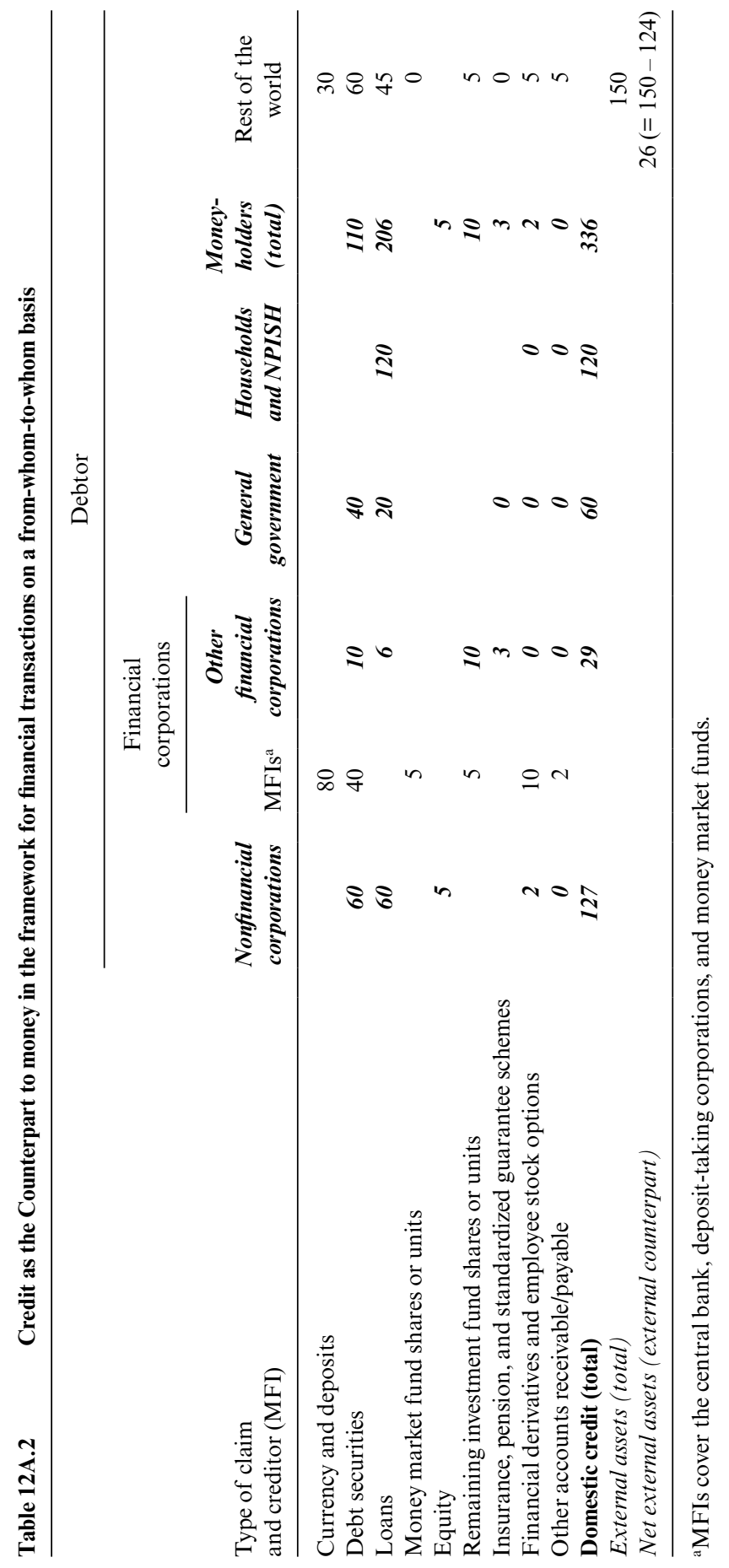




\section{Appendix B}

\section{A Status of Availability of Sectoral Balance Sheets and Accumulation Accounts in G-20 Economies}

As a first step of a program to strengthen the development and dissemination of sectoral accounts and balance sheets, the IMF Statistics Department has conducted a review of the availability of sectoral balance sheets and accumulation accounts disseminated by the G-20 economies. For each country the review examined the scope and details of the data officially disseminated and made available to the general public through the countries' statistical institutions (national statistical offices, central banks, and ministries of finance) or through OECD, ECB, and Eurostat. The review was focused on the existence of sectoral accounts within the framework of SNA. Information was gathered for stocks, transactions, and other flows of nonfinancial assets and stocks, transactions and other flows of financial assets and liabilities, using the classification of assets and liabilities as well as the classification of institutional sectors as established in the 2008 SNA at the first-digit level (and second digit in some cases) of the corresponding classifications. Note was taken when additional details were available, but without a thorough review of the details published by each country. Other main data characteristics (such as data frequency, timeliness, dissemination formats, and time series) were also reviewed. The IMF review of data availability was conducted during late 2010 and was presented at the IMF-OECD conference in early $2011 .{ }^{27}$ This appendix presents the updated status on the availability of sectoral balance sheets and accumulations accounts in the G-20 economies as of the end of 2012.

Progress in the availability of the sectoral balance sheets and accumulation accounts in the G-20 economies since the IMF review has been incorporated and presented in the appendix tables 12B.2 and 12B.3. This exercise does not provide an assessment of the quality and accuracy of data. It should also be noted that this assessment is conducted to provide a broad indication of data gaps for the G-20 economies with respect to sectoral balance sheets and accumulation accounts, and therefore, the assessment for a country may not be comprehensive and fully accurate.

Appendix table 12B.1 shows the classification of assets and liabilities that was used in reviewing the availability of data on sectoral balance sheets and accumulation accounts. The main SNA breakdown of institutional sectors in appendix table 12B.2 and 12B.3 refers to (a) financial corporations, (b) nonfinancial corporations, (c) general governments, (d) households and nonprofit institutions serving households, and (e) the rest of the world. The

27. Shrestha (2011). 
Table 12B.1 Classification of assets and liabilities used in the review of data availability

\begin{tabular}{ll}
\hline Nonfinancial assets & \multicolumn{1}{c}{ Financial instruments } \\
\hline Fixed assets & Monetary gold and SDRs \\
Dwellings & Currency \\
Inventories & Transferable deposits \\
Valuables & Transferable deposits with nonresidents \\
Nonproduced assets & Other deposits \\
Natural resources & Other deposits with nonresidents \\
Contracts, leases and licenses & Debt securities \\
& Debt securities short term \\
& Debt securities short term with residents \\
& Debt securities short term with nonresidents \\
& Debt securities long term \\
& Debt securities long term with residents \\
& Debt securities long term with nonresidents \\
& Loans \\
Loans short term \\
Loans short term with residents \\
Loans short term with nonresidents \\
Loans long term \\
Loans long term with residents \\
Loans long term with residents-mortgages \\
Loans long term with nonresidents \\
Equity and investment fund shares \\
Investment fund shares \\
Insurance, pension, and standardized guarantee schemes \\
Financial derivatives and employee stock options \\
Other accounts receivable/payable \\
\hline
\end{tabular}

main SNA financial instrument breakdown used in appendix table 12B.2 comprise (a) monetary gold and SDRs, (b) currency and deposits, (c) debt securities, (d) loans, (e) equity and investment fund shares, (f) insurance, pension, and standardized guarantee schemes, and (g) other accounts receivable/payable. The main SNA breakdown of nonfinancial assets in appendix table 12B.3 includes (a) fixed assets, (b) inventories, (c) valuables, and (d) nonproduced assets. 


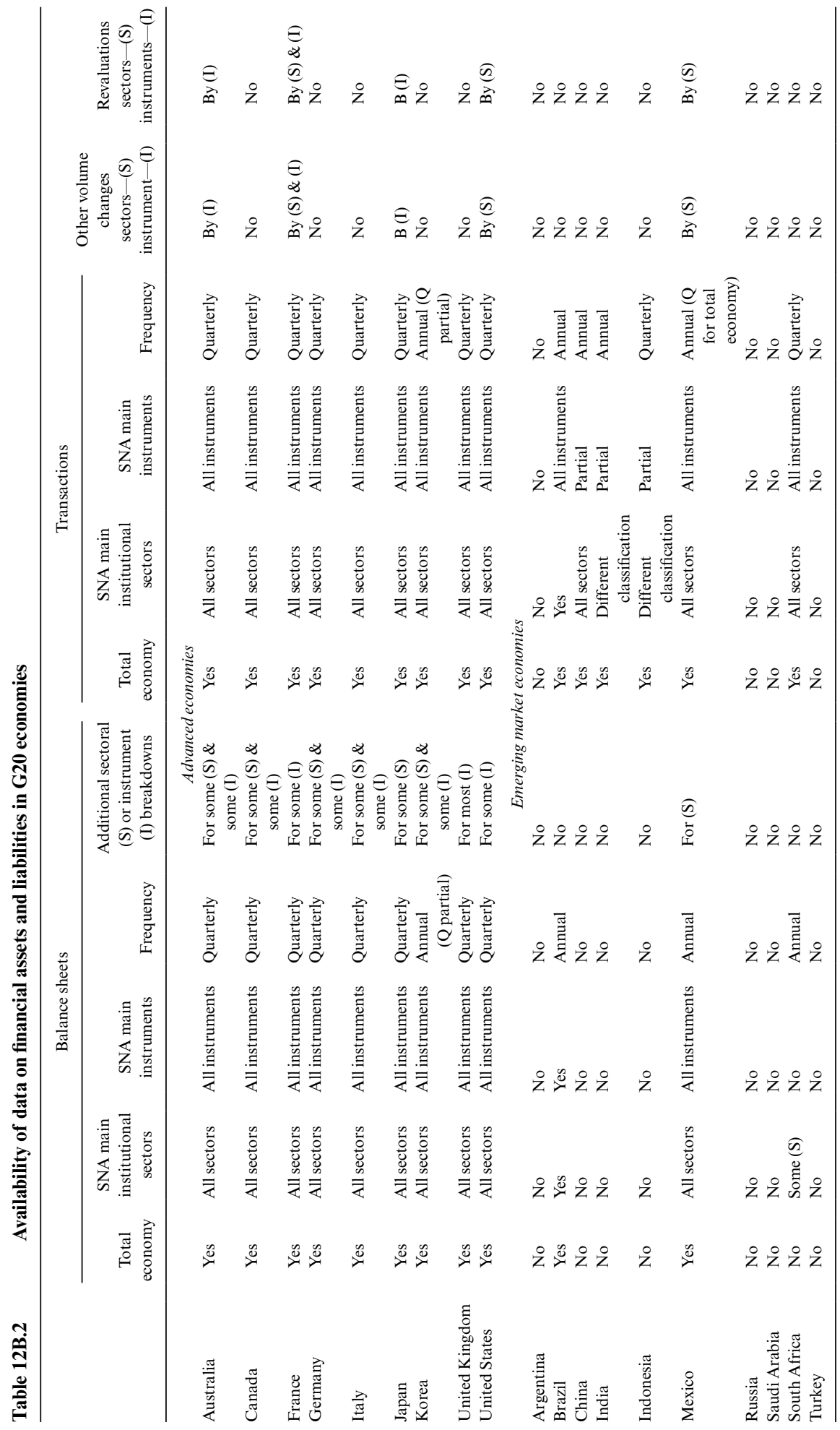




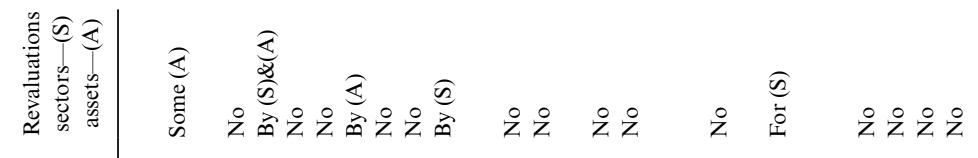

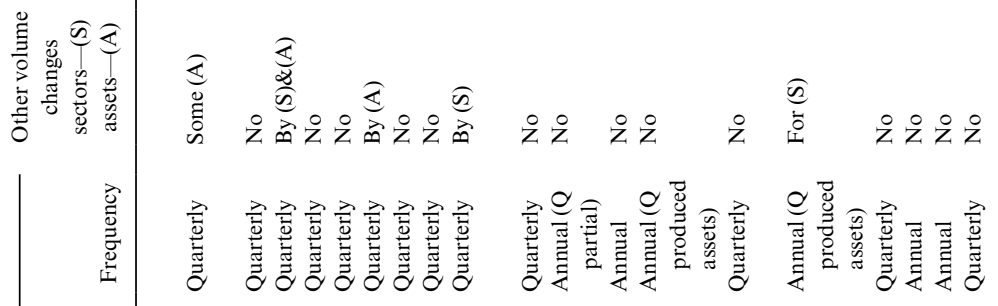

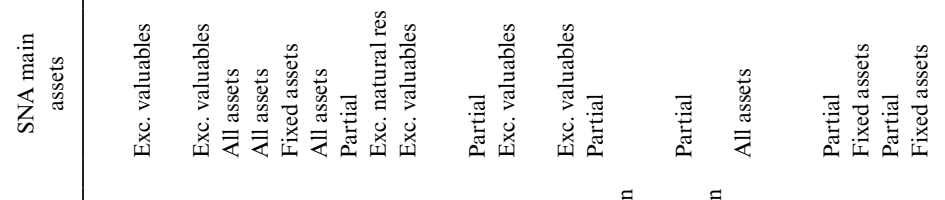

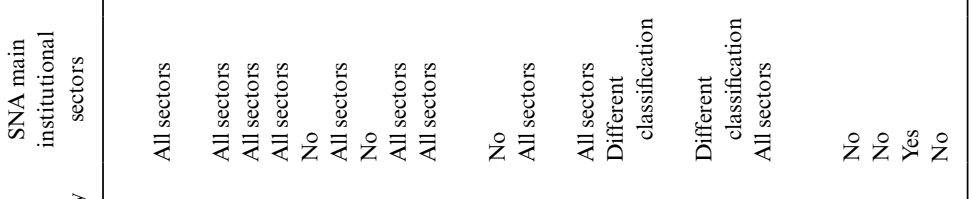
焉窟

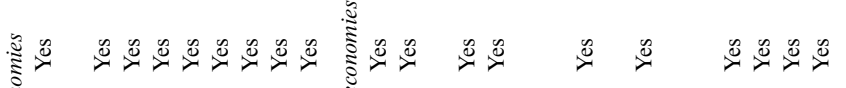

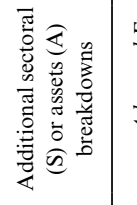

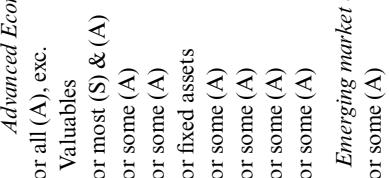

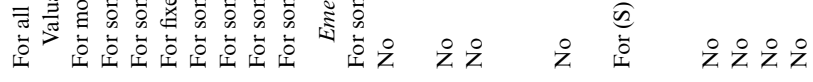

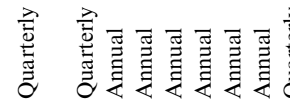

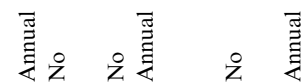

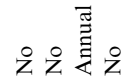

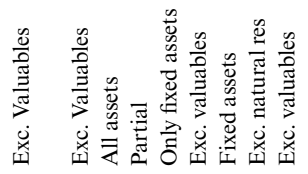

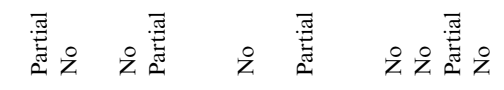

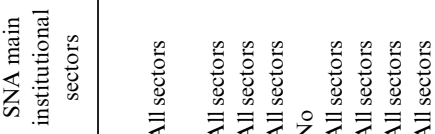

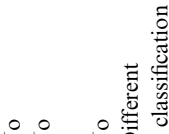
픙 륭

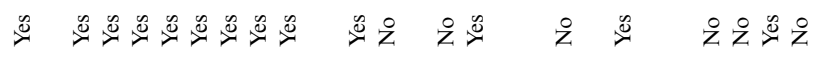




\section{Appendix C}

\section{Presentation of Sectoral Financial Positions and Flows}

As a first step, tables may be designed to follow the residence of creditor approach. Such tables show institutional sectors as creditors that hold financial instruments. The holdings are part of the balance sheet (asset portfolio) of this sector, whereas transactions in financial instruments are part of the sector's financial account. The holdings of financial instruments by resident sectors are shown (with a breakdown by the residency of debtors but without a breakdown of the resident sector of debtors), and the financial instruments issued by residents and acquired by nonresidents are also shown. Appendix table 12C.1 reflects this approach and shows the financial instrument categories according to the 2008 SNA.

Some amendments to this table may be made by splitting the financial corporation sector into some subsectors, such as depository corporations, insurance corporations and pension funds, and other financial corporations. A breakdown of some financial instrument categories, such as deposits, loans, or debt securities by original maturity may also be feasible at this stage.

The tables on the from-whom-to-whom basis show positions and flows for financial instruments acquired by resident sectors and by nonresidents, with a breakdown by institutional sector for resident debtors (the cells of appendix table 12C.2 shaded light gray). Furthermore, acquisitions by nonresidents of financial instruments issued by residents are shown (penultimate column marked nonresidents) and also financial instruments issued by nonresidents and acquired by resident sectors (penultimate row marked nonresidents). However, acquisitions by nonresidents of financial instruments issued by nonresidents are not covered (black cells).

For residents, the presentation of nonconsolidated data on the holdings and acquisitions of financial instruments is recommended, covering intrasectoral positions and flows (diagonal cells of appendix table 12C.2 shaded in dark gray).

The collection and compilation of such from-whom-to-whom data has to follow a step-by-step approach based on the availability of corresponding source data. A first step is usually to integrate such data from monetary statistics, balance of payments, or government finance statistics providing usually detailed data on nonnegotiable financial instruments, such as deposits, loans, trade credit, or insurance and pension entitlements.

In a further step, from-whom-to-whom data may be derived by sector and subsector for securities based on detailed source data taken from financial statements and from securities databases. When developing data sources and a compilation system for sectoral financial positions and flows, it is important to design them with a view to supporting the broader objective of the compilation of integrated sectoral financial positions and flows on a from-whom-to-whom basis. 


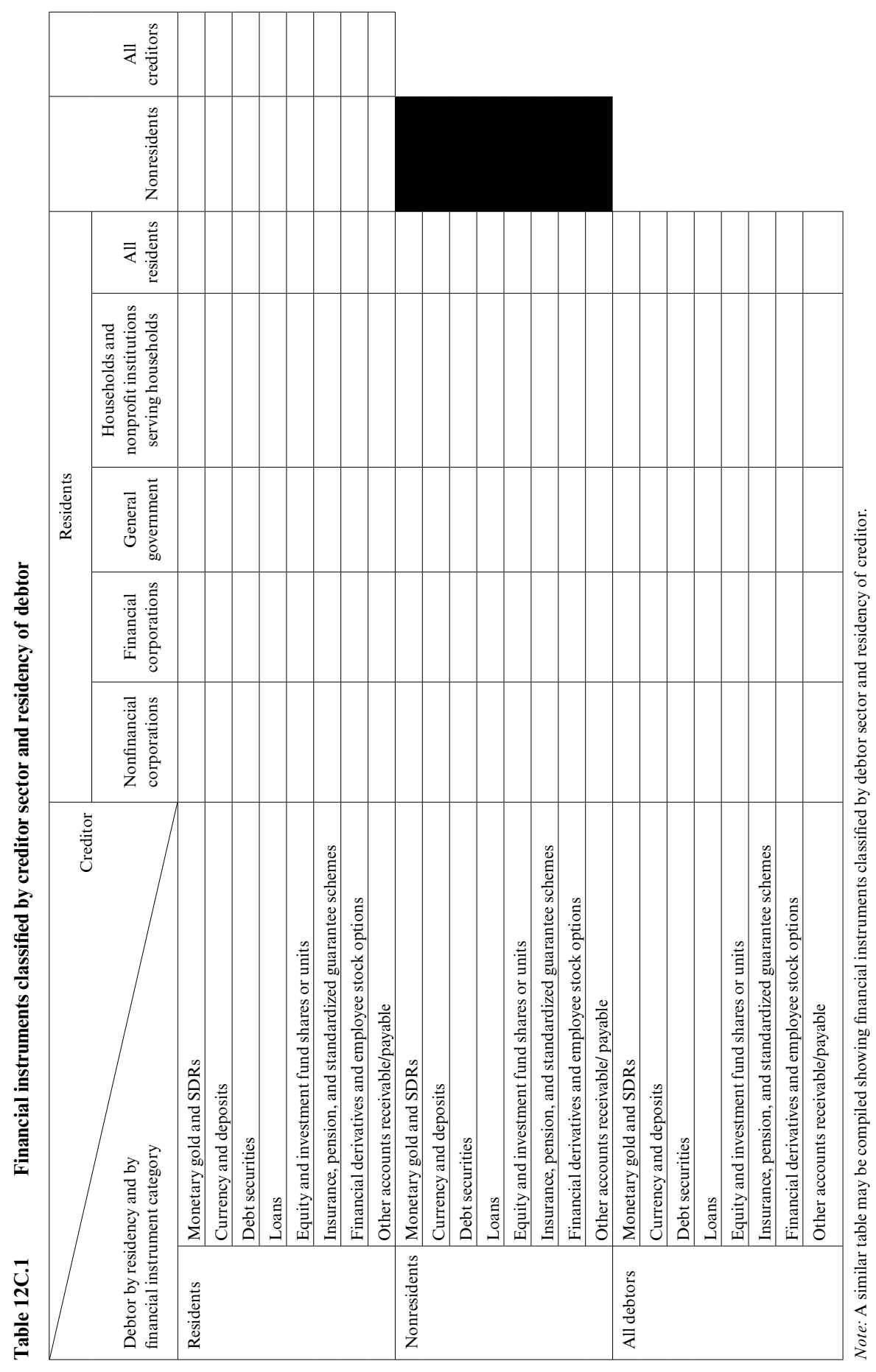




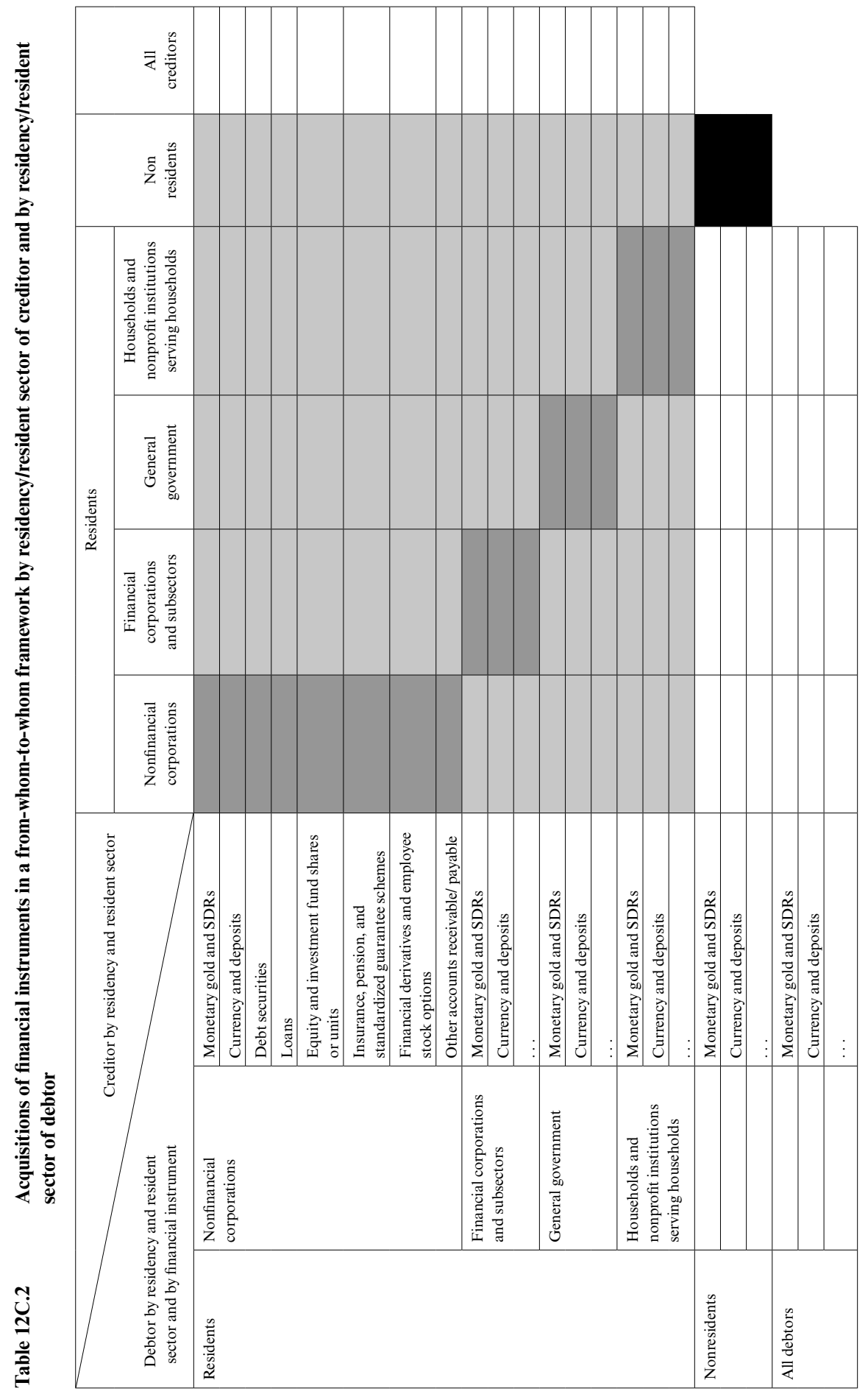




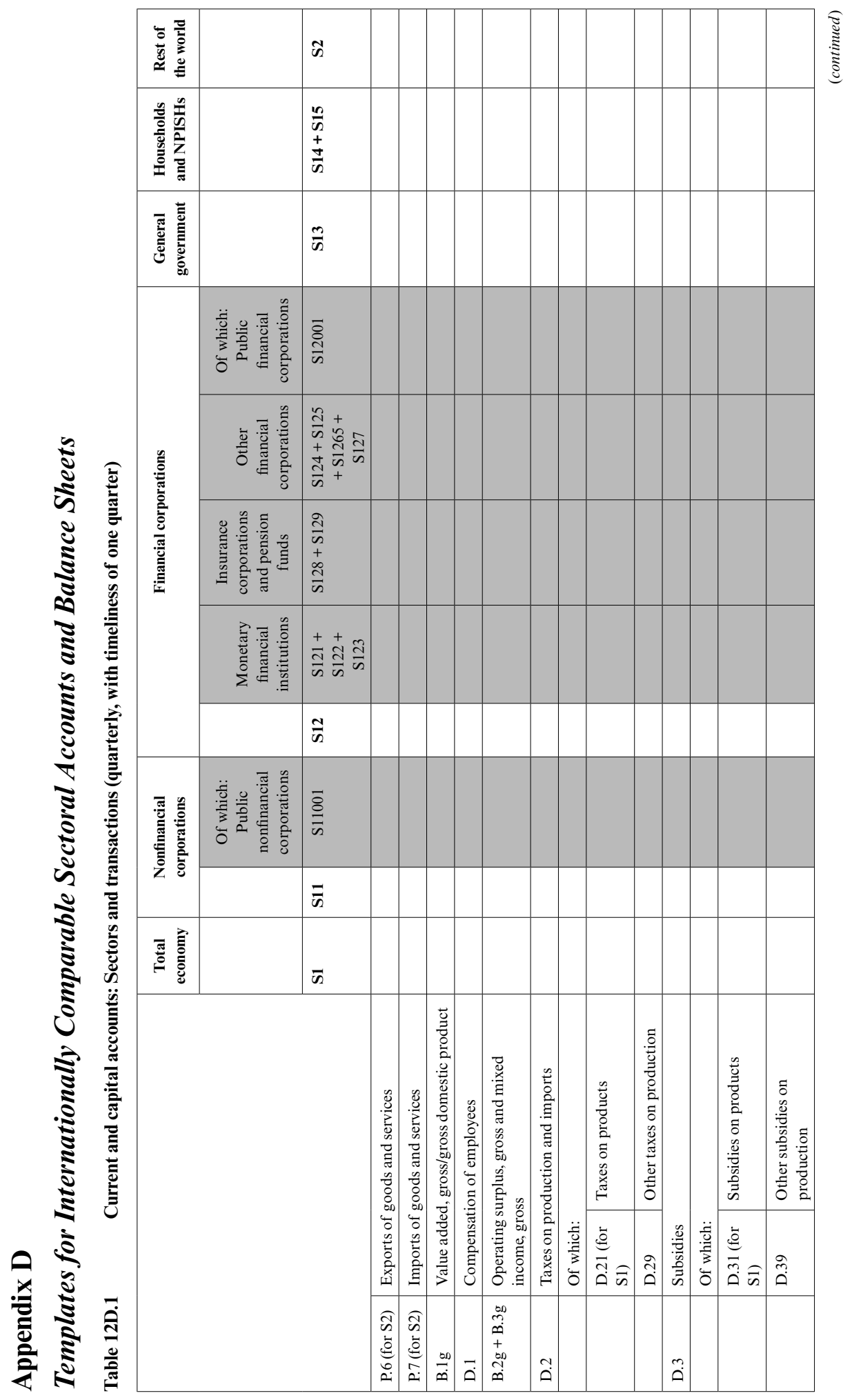




\begin{tabular}{|c|c|c|c|c|c|c|c|c|c|c|c|c|c|c|c|c|c|c|}
\hline 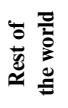 & & $\tilde{\omega}$ & & & & & & & & & & & & & & & & \\
\hline 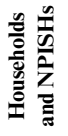 & & $\begin{array}{l}\frac{n}{n} \\
+ \\
\frac{ \pm}{n}\end{array}$ & & & & & & & & & & & & & & & & \\
\hline 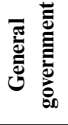 & & $\frac{m}{n}$ & & & & & & & & & & & & & & & & \\
\hline \multirow{5}{*}{ 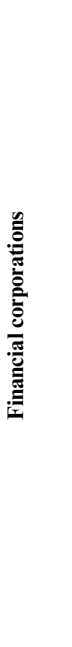 } & 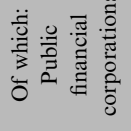 & $\begin{array}{l}\overline{\tilde{O}} \\
\bar{\omega}\end{array}$ & & & & & & & & & & & & & & & & \\
\hline & 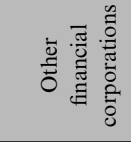 & 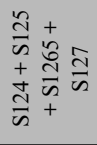 & & & & & & & & & & & & & & & & \\
\hline & 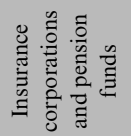 & $\begin{array}{l}\text { ते } \\
\text { n } \\
+ \\
\infty \\
\stackrel{\sim}{n}\end{array}$ & & & & & & & & & & & & & & & & \\
\hline & 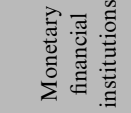 & 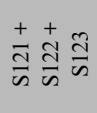 & & & & & & & & & & & & & & & & \\
\hline & & $\tilde{a}$ & & & & & & & & & & & & & & & & \\
\hline \multirow{2}{*}{ 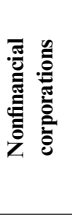 } & 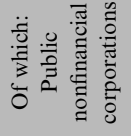 & $\frac{\bar{\delta}}{\bar{n}}$ & & & & & & & & & & & & & & & & \\
\hline & & $\overline{\bar{n}}$ & & & & & & & & & & & & & & & & \\
\hline 产 & & $\bar{n}$ & & & & & & & & & & & & & & & & \\
\hline & & & 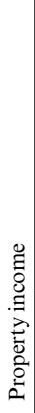 & 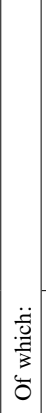 & 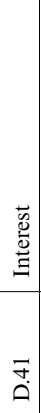 & 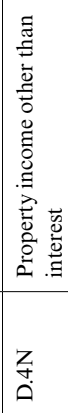 & 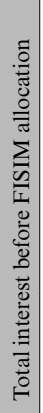 & 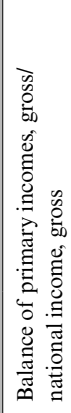 & 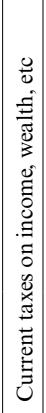 & 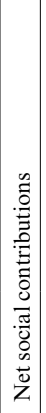 & 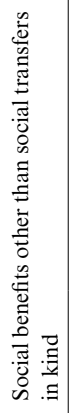 & 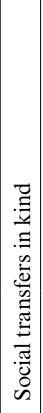 & 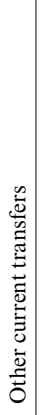 & \begin{tabular}{|c|} 
\\
\\
$\frac{3}{0}$ \\
$\frac{0}{3}$ \\
$\frac{3}{0}$ \\
0
\end{tabular} & 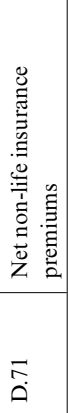 & 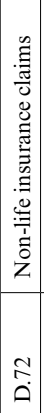 & 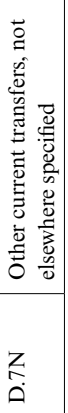 & 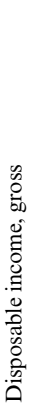 \\
\hline & & & $\stackrel{t}{\circ}$ & & & & 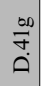 & $\mid \begin{array}{l}\infty \\
\infty \\
\infty \\
\infty\end{array}$ & $\stackrel{n}{a}$ & $\begin{array}{l}\vec{b} \\
\dot{0}\end{array}$ & 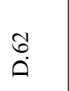 & : & 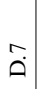 & & & & & 每 \\
\hline
\end{tabular}




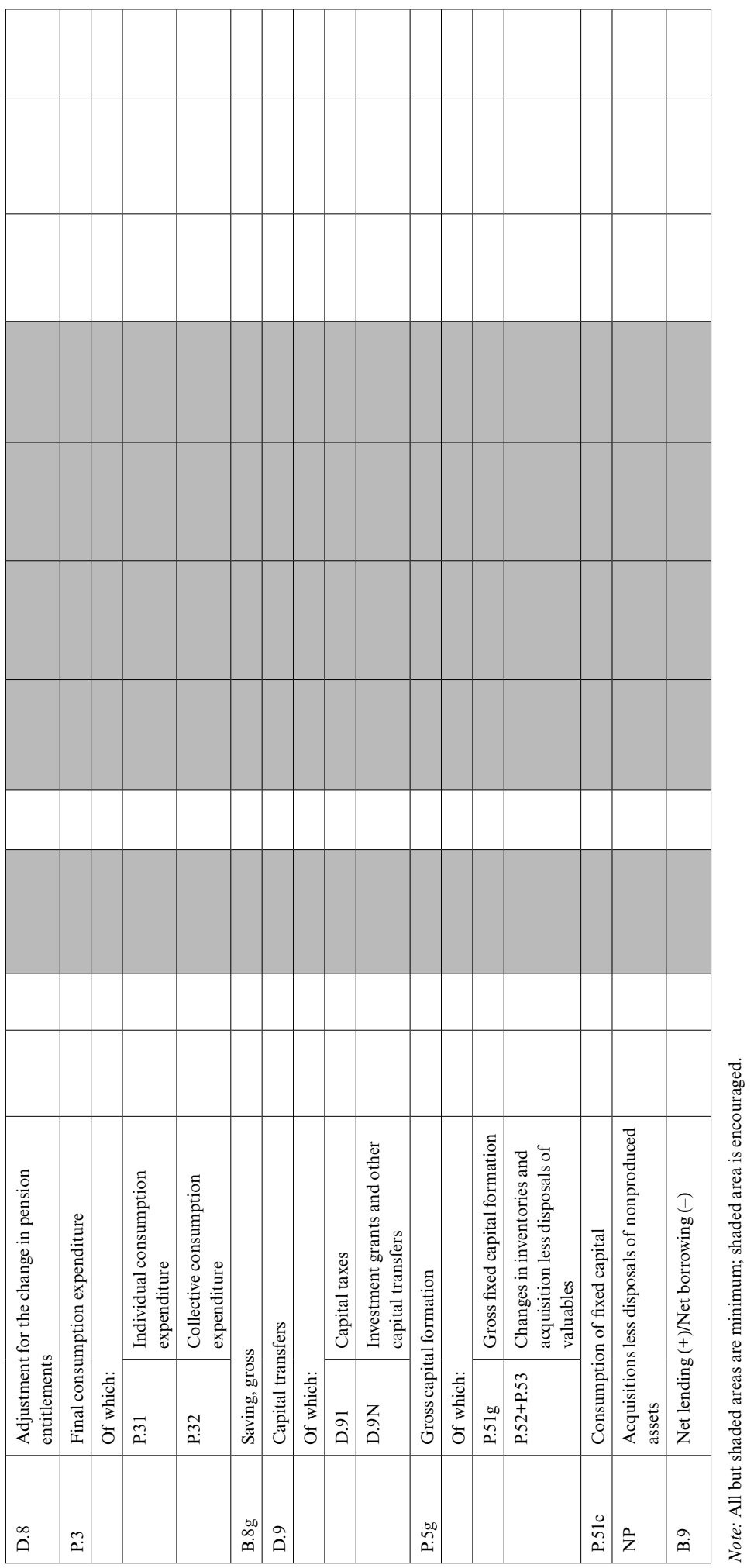




\begin{tabular}{|c|c|c|c|c|c|c|c|c|c|c|}
\hline & 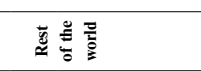 & $\approx$ & & & & & & & & \\
\hline & $\frac{n}{\hat{x}_{2}^{2}}$ & $\frac{n}{n}$ & & & & & & & & \\
\hline & 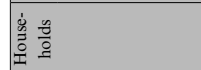 & $\frac{5}{n}$ & & & & & & & & \\
\hline & 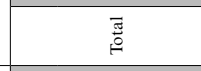 & $\frac{ \pm \frac{n}{n}}{n}$ & & & & & & & & \\
\hline & 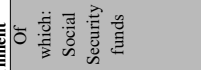 & $\frac{ \pm}{\frac{m}{n}}$ & & & & & & & & \\
\hline & 票 & $\frac{2}{n}$ & & & & & & & & \\
\hline & 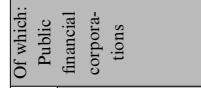 & $\frac{\overline{2}}{\bar{n}}$ & & & & & & & & \\
\hline & 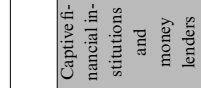 & $\frac{\pi}{n}$ & & & & & & & & \\
\hline & 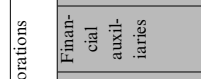 & $\frac{\%}{\pi}$ & & & & & & & & \\
\hline & 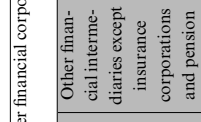 & 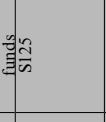 & & & & & & & & \\
\hline & 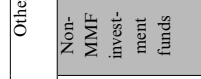 & $\frac{\vec{H}}{\vec{n}}$ & & & & & & & & \\
\hline & 竞 & 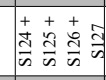 & & & & & & & & \\
\hline & 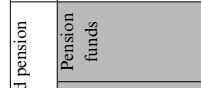 & $\frac{2}{n}$ & & & & & & & & \\
\hline & 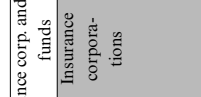 & $\frac{0}{n}$ & & & & & & & & \\
\hline & 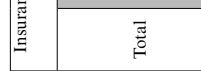 & $\frac{\infty}{n}+\frac{2}{n}$ & & & & & & & & \\
\hline & 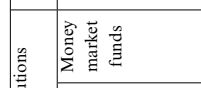 & $\frac{\pi}{n}$ & & & & & & & & \\
\hline & 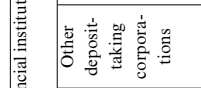 & $\frac{\pi}{n}$ & & & & & & & & \\
\hline & 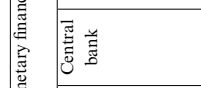 & $\frac{\pi}{n}$ & & & & & & & & \\
\hline & 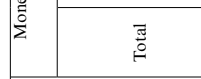 & 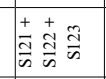 & & & & & & & & \\
\hline & 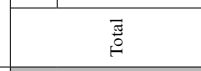 & $\frac{\pi}{n}$ & & & & & & & & \\
\hline & 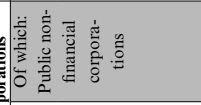 & $\overline{\frac{8}{2}}$ & & & & & & & & \\
\hline & 言 & $\overline{\bar{n}}$ & & & & & & & & \\
\hline & 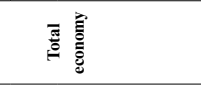 & $\bar{n}$ & & & & & & & & \\
\hline & & & $\frac{\pi}{\bar{z}}$ & 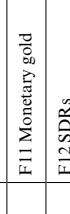 & & 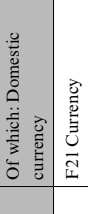 & 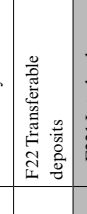 & 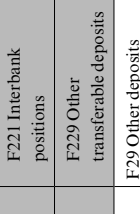 & 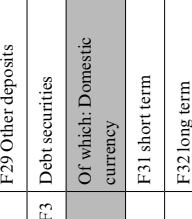 & 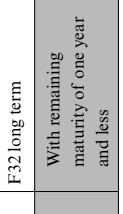 \\
\hline
\end{tabular}




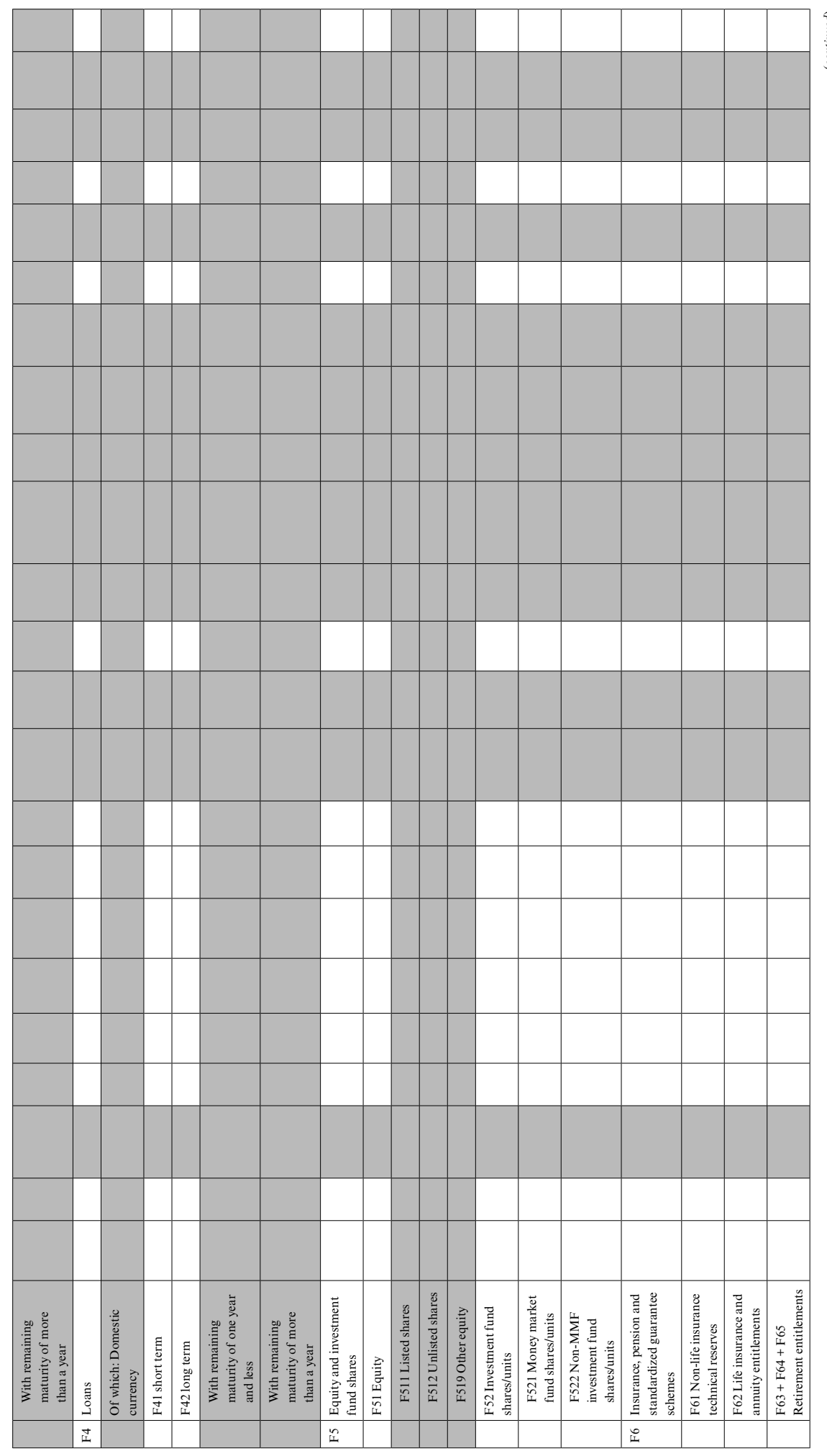




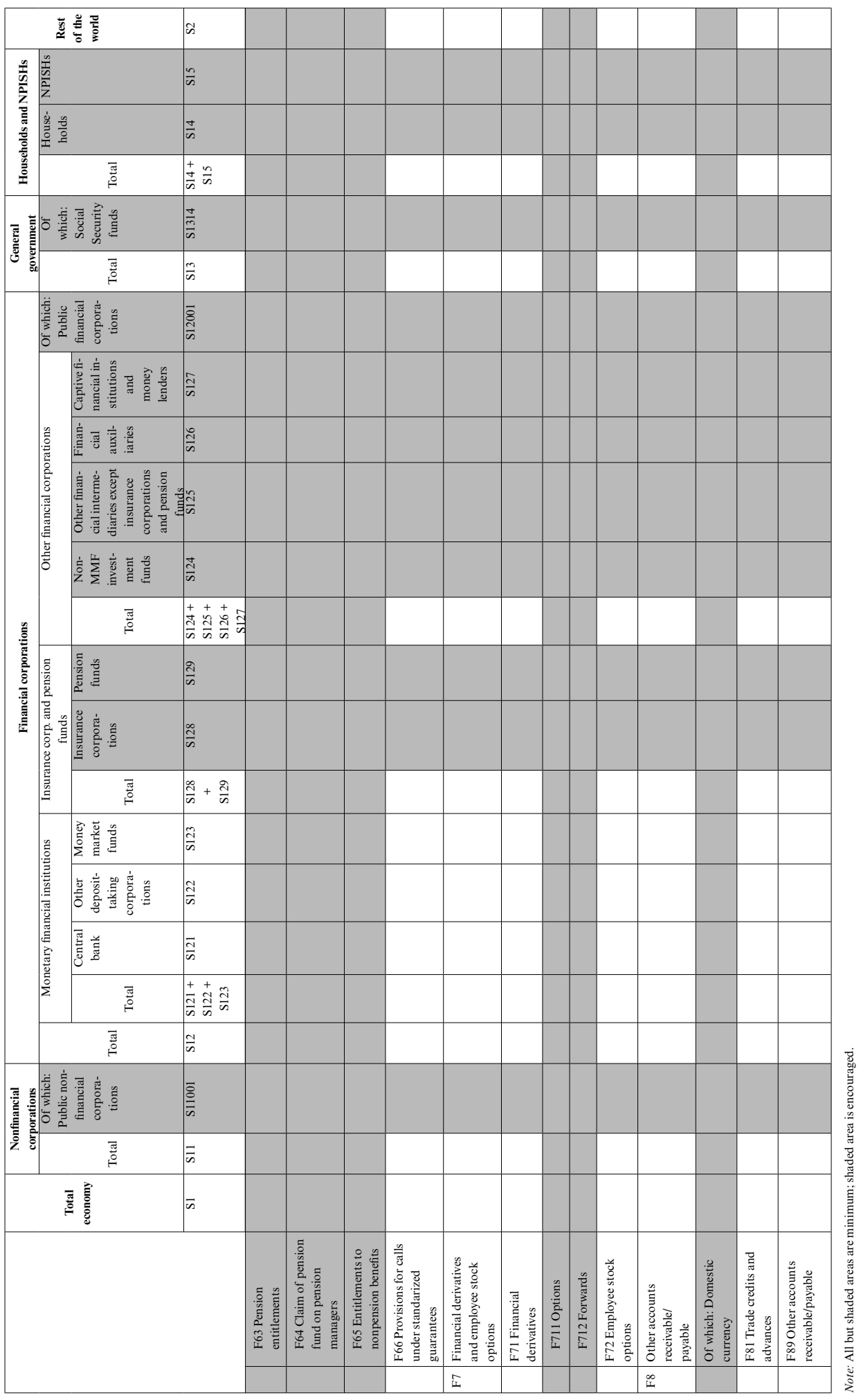




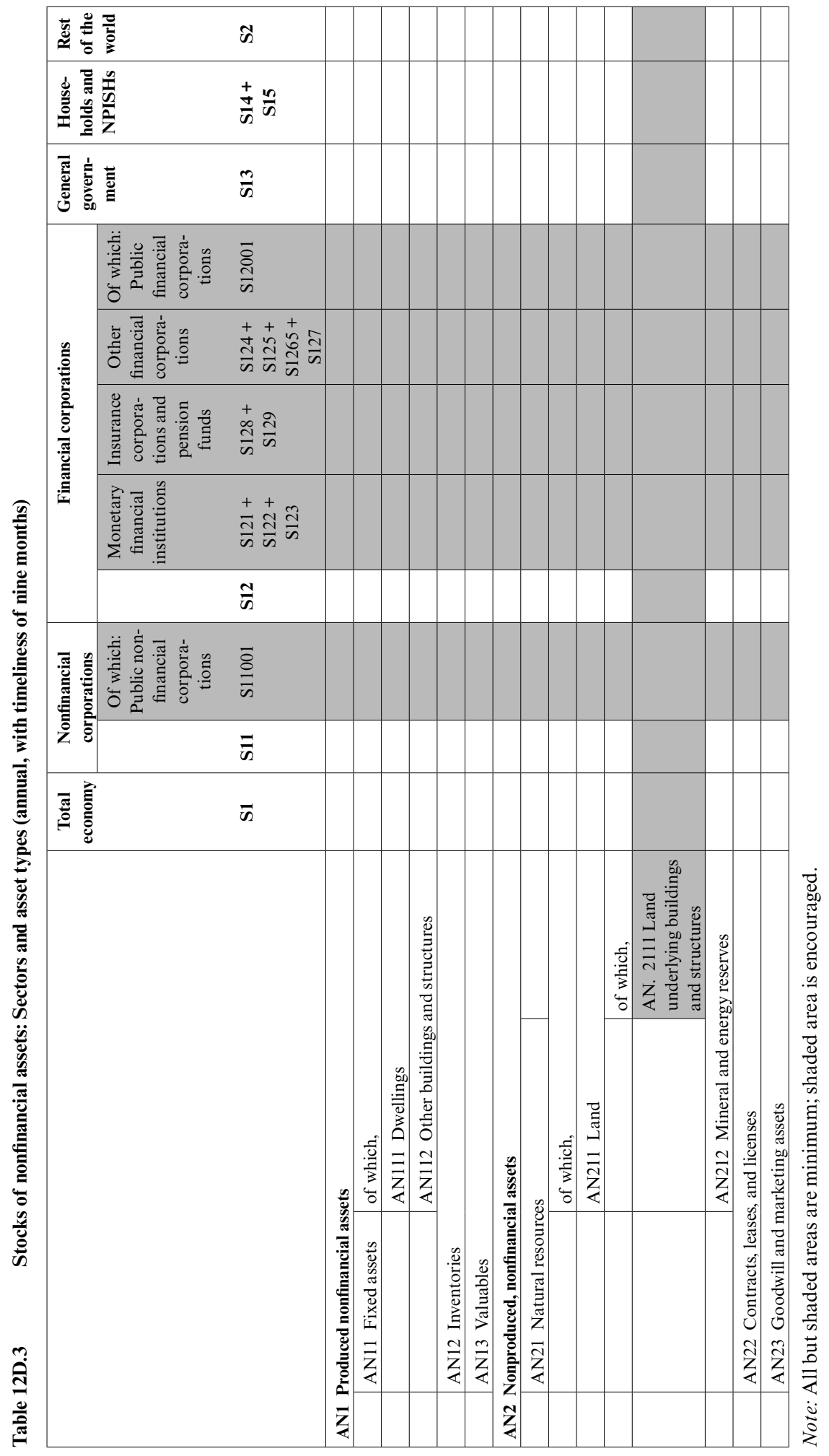




\section{References}

Allen, M., C. Rosenberg, C. Keller, B. Setser, and Nouriel Roubini. 2002. "A Balance Sheet Approach to Financial Crisis." IMF Working Paper no. WP/02/210. http:// www.imf.org/external/pubs/cat/longres.aspx?sk=16167.0.

Bank for International Settlements, International Monetary Fund, and European Central Bank. Various Years. Handbook on Securities Statistics, Part 1, Part 2, and Part 3. http://www.imf.org/external/np/sta/wgsd/hbook.htm.

Bank for International Settlements. Locational International Banking Statistics Guide and Data. http://www.bis.org/statistics/bankstats.htm.

Dawson, John C., ed. 1996. Flow of Funds Analysis, A Handbook for Practitioners, Armonk and London.

European Central Bank. 2012. Handbook on Quarterly Financial Accounts for the Euro Area: Sources and Methods. http://www.ecb.int/stats/acc/html/index.en.html.

European Central Bank. 2010. ECB Monthly Bulletin-Euro Area Statistics Methodological Notes: Chapter 3 Euro Area Accounts. http://www.ecb.int/stats/acc/html /index.en.html.

European Central Bank. 2004. "Properties and Use of General Government Quarterly Accounts." Monthly Bulletin August: 65-77.

European Central Bank. 2006. "Sectoral Money Holding: Determinants and Recent Developments." Monthly Bulletin August.

European Central Bank. 2006. Integrated Financial and Non-Financial Accounts for the Institutional Sectors in the Euro Area. Frankfurt am Main: European Central Bank. October.

European Council. 1996. European System of Accounts (ESA95). Brussels.

Eurostat. 2012. European System of Accounts (ESA2010), draft version.

Financial Stability Board and International Monetary Fund. 2009. The Financial Crisis and Information Gaps - Report to the G-20 Finance Ministers and Central Bank Governors. Washington, D.C. http://www.imf.org/external/np/g20/pdf/102909.pdf.

Financial Stability Board and International Monetary Fund. 2011. The Financial Crisis and Information Gaps - Implementation Progress Report. Washington, D.C. http://www.imf.org/external/np/g20/pdf/063011.pdf.

Heath, R. 2013. "Why are the G-20 Data Gaps Initiative and the SDDS Plus Relevant for Financial Stability Analysis?"IMF Working Paper no. WP/13/6. http://www .imf.org/external/pubs/cat/longres.aspx?sk=40227.0.

International Monetary Fund. 2009. Balance of Payments and International Investment Position Manual, Sixth Edition (BPM6). Washington, D.C.

International Monetary Fund. 2000. Monetary and Financial Statistics Manual. Washington, D.C.

International Monetary Fund. 2001. Government Finance Statistics Manual, Washington, D.C.

International Monetary Fund. CDIS Guide, Data, Metadata. Washington, D.C. http://www.imf.org/external/np/sta/pi/ cdis/index.htm.

International Monetary Fund. CPIS Guide, Data, Metadata. Washington, D.C. http://www.imf.org/external/np/sta/pi/ cpis.htm.

Mathisen, J., and A. Pellechio. 2006. "Using the Balance Sheet Approach in Surveillance: Framework and Data Sources and Availability."IMF Working Paper no. WP/06/100. http://www.imf.org/external/pubs/cat/ longres.aspx?sk=19800.0.

Shrestha, M. 2011. "A Status on the Availability of Sectoral Balance Sheets and Accumulation Accounts in G20 Economies." Paper presented at the IMF-OECD Conference on Strengthening Sectoral Position and Flow Data in the Macro- 
economic Accounts, Washington, DC, February 28-March 2. http://www.imf.org /external/np/seminars/eng/2011/sta/index.htm.

Shrestha, M., R. Mink, and S. Fassler. 2012. "An Integrated Framework for Financial Positions and Flows on a From-Whom-to-Whom Basis: Concepts, Current Status, and Prospects." IMF Working Paper no. (WP/12/57). http://www.imf.org /external/pubs/cat/longres.aspx?sk=25743.0.

United Nations, Eurostat, International Monetary Fund, Organisation for Economic Co-operation and Development and World Bank. 1993. System of National Accounts 1993, Series F, No. 2, Rev. 4. New York: United Nations.

United Nations, European Commission, International Monetary Fund, Organisation for Economic Co-operation and Development and World Bank. 2009. System of National Accounts 2008, Series F, No. 2, Rev. 5. New York: United Nations. 